\title{
Lipoxin and Aspirin-Triggered Lipoxins
}

\author{
Mario Romano \\ Department of Biomedical Sciences, Aging Research Center, Ce.S.I., "Gabriele \\ D’Annunzio" University Foundation, Chieti, Italy \\ E-mail: mromano@unich.it
}

Received March 7, 2010; Revised May 7, 2010; Accepted May 13, 2010; Published June 2, 2010

Lipoxins and their 15 epimers, aspirin triggered lipoxins (ATL), are eicosanoids derived from sequential lipoxygenase (LO) metabolism of arachidonic acid. The main routes of lipoxin biosynthesis involve cooperation between 15- and 5-LO, and between 12- and 5LO. ATL are generated by interactions between 5-LO and aspirin-acetylated cyclooxygenase-2. Cellular models recapitulating these interactions involve leukocytes, platelets, vascular endothelium, and epithelium. To circumvent rapid lipoxin and ATL metabolism and inactivation, stable analogs, bearing potent and long-lasting biological activity, have been synthesized. Some of these analogs displayed therapeutic potential by showing strong anti-inflammatory activity in a number of animal models of disease, including reperfusion injury; arthritis; gastrointestinal, renal, respiratory, and vascular inflammatory disorders; eye damage; periodontitis; and selected infectious diseases. Counter-regulatory signaling by lipoxin $A_{4}$ and 15-epi-lipoxin $A_{4}$ is triggered by the activation of a seven-transmembrane domain receptor, termed FPR2/ALX, which is highly expressed in myeloid cells and has been recognized as a main anti-inflammatory receptor.

KEYWORDS: arachidonic acid, lipoxin, lipoxygenase, cyclooxygenase, inflammation, aspirin, receptor

\section{STRUCTURE}

The presence of polar compounds carrying a conjugated tetraene chromophore was first revealed in incubations of human leukocytes with arachidonic acid or $15 S$-hydroperoxy-5,8,11,13-eicosatetraenoic acid (HpETE)[1,2]. Structure elucidation of the compounds formed during these incubations revealed $5 S, 6 R, 15 S$-trihydroxy-7,9,13-trans-11-cis-eicosatetraenoic acid and 5S,14R,15S-trihydroxy-6,10,12-trans8-cis-eicosatetraenoic acid, which were termed, respectively, lipoxin $\mathrm{A}_{4}$ and lipoxin $\mathrm{B}_{4}$ (Fig. 1), where lipoxin stands for lipoxygenase interaction products. The UV absorption spectrum of both lipoxin $\mathrm{A}_{4}$ and $\mathrm{B}_{4}$ shows pre-eminent absorbance bands at $\lambda_{\max }^{\mathrm{MeOH}} 287,300$, and $315 \mathrm{~nm}$, with a weaker band at $270 \mathrm{~nm}$ and a molar extinction coefficient of $50,000 \mathrm{M}^{-1} / \mathrm{cm}$. Monitored using negative ion mode mass spectrometry with electrospray ionization, lipoxins yield $[\mathrm{M}-\mathrm{H}]-$ parent ions of $351 \mathrm{~m} / \mathrm{z}$ and diagnostic MS/MS product ions at $\mathrm{m} / \mathrm{z} 333\left[351-\mathrm{H}_{2} \mathrm{O}\right], \mathbf{3 1 5}\left[351-2 \mathrm{H}_{2} \mathrm{O}\right], 307\left[351-\mathrm{CO}_{2}\right], 289$ [351- $\left.\mathrm{H}_{2} \mathrm{O}-\mathrm{CO}_{2}\right], 271$ $\left[351-2 \mathrm{H}_{2} \mathrm{O}-\mathrm{CO}_{2}\right], \quad 251 \quad\left[351-\mathrm{CHO}\left(\mathrm{CH}_{2}\right)_{4} \mathrm{CH}_{3}\right], \quad 235 \quad\left[351-\mathrm{CHO}\left(\mathrm{CH}_{2}\right)_{3} \mathrm{COO}^{-}\right], \quad 233 \quad\left[351-\mathrm{H}_{2} \mathrm{O}-\right.$ $\mathrm{CHO}\left(\mathrm{CH}_{2}\right)_{4} \mathrm{CH}_{3}$ ], 219 [351- $\left.\mathrm{CHO}\left(\mathrm{CH}_{2}\right)_{3} \mathrm{COO}^{-} \mathrm{O}\right], 207$ [351- $\mathrm{CO}_{2}-\mathrm{CHO}\left(\mathrm{CH}_{2}\right)_{4} \mathrm{CH}_{3}$ ], 189 [351- $\mathrm{H}_{2} \mathrm{O}-\mathrm{CO}_{2^{-}}$ 


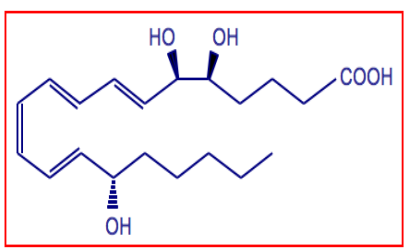

Lipoxin $\mathrm{A}_{4}$

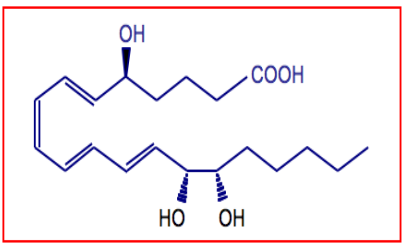

Lipoxin $\mathrm{B}_{4}$

FIGURE 1. Chemical structures of lipoxin $\mathrm{A}_{4}$ and $\mathrm{B}_{4}$.

$\left.\mathrm{CHO}\left(\mathrm{CH}_{2}\right)_{4} \mathrm{CH}_{3}\right], 135$ [351- $\left.\mathrm{CHO}\left(\mathrm{CH}_{2}\right)_{3}-\mathrm{COOH}-\mathrm{CHO}\left(\mathrm{CH}_{2}\right)_{4} \mathrm{CH}_{3}\right], 115\left[\mathrm{CHO}\left(\mathrm{CH}_{2}\right)_{3} \mathrm{COO}^{-}\right]$for lipoxin $\mathrm{A}_{4}$, and $m / z 333\left[351-\mathrm{H}_{2} \mathrm{O}\right], 315\left[351-2 \mathrm{H}_{2} \mathrm{O}\right], 307$ [351- $\left.\mathrm{CO}_{2}\right], 289$ [351- $\left.\mathrm{H}_{2} \mathrm{O}-\mathrm{CO}_{2}\right], 271\left[351-2 \mathrm{H}_{2} \mathrm{O}-\mathrm{CO}_{2}\right], 251$ [351- $\mathrm{CHO}\left(\mathrm{CH}_{2}\right)_{4} \mathrm{CH}_{3}$ ], 233 [351- $\mathrm{H}_{2} \mathrm{O}-\mathrm{CHO}\left(\mathrm{CH}_{2}\right)_{4} \mathrm{CH}_{3}$ ], 221 [351-CHOCHOH $\left(\mathrm{CH}_{2}\right)_{4} \mathrm{CH}_{3}$ ], 207 [351$\left.\mathrm{CO}_{2}-\mathrm{CHO}\left(\mathrm{CH}_{2}\right)_{4} \mathrm{CH}_{3}\right], 189$ [351- $\mathrm{H}_{2} \mathrm{O}-\mathrm{CO}_{2}-\mathrm{CHO}\left(\mathrm{CH}_{2}\right)_{4} \mathrm{CH}_{3}$ ], 163 [351- $\mathrm{CO}_{2}-\mathrm{CH}_{2} \mathrm{COHCHOH}\left(\mathrm{CH}_{2}\right)_{4} \mathrm{CH}_{3}$ ], $129\left[\mathrm{CH}_{3} \mathrm{CO}\left(\mathrm{CH}_{2}\right)_{3} \mathrm{COO}^{-}\right]$and $115\left[\mathrm{CHO}\left(\mathrm{CH}_{2}\right)_{3} \mathrm{COO}^{-}\right]$for lipoxin $\mathrm{B}_{4}$.

Although a number of lipoxin $\mathrm{A}_{4}$ and $\mathrm{B}_{4}$ isomers have been identified in vitro, their biological significance remains incompletely defined[3,4].

\section{BIOSYNTHESIS}

Lipoxins and ATL are generated by cooperation between lipoxygenase isoforms and aspirin-acetylated cyclooxygenase-2 (COX-2) and 5-lipoxygenase (5-LO), respectively. Two main routes of lipoxin biosynthesis have been characterized: the 5-/15-LO and the 5-/12-LO.

\section{The 5-/15-LO Pathway}

This pathway can be alternatively initiated by 5- or 15-LO. In one case, 5-LO converts arachidonic acid to leukotriene (LT) $\mathrm{A}_{4}$, which is further metabolized by $15-\mathrm{LO}$ to a $5 S, 6 \mathrm{~S}, 15 \mathrm{~S}$-epoxytetraene intermediate, enzymatically transformed into lipoxin $\mathrm{A}_{4}$ and $\mathrm{B}_{4}$. In the other event, arachidonic acid is converted by $15-$ LO into HpETE, which is reduced to $15 S$-hydroxy eicosatetreanoic acid (HETE) by a peroxidase. $15 S$ HpETE and $15 S$-HETE are transformed by 5 -LO into the $5 S, 6 S, 15 S$-epoxytetraene intermediate, which yields both lipoxin $\mathrm{A}_{4}$ and $\mathrm{B}_{4}[5]$. Cellular models for this biosynthetic route are human polymorphonuclear neutrophils (PMNs) (Fig. 2A)[6], eosinophils[7], alveolar macrophages[8], or interactions between PMNs and eosinophils[7], or PMNs and lung tissue (Fig. 2B)[9]. The 5-/15-LO pathway appears to be predominant in the respiratory tract and it may be relevant within the brain, since lipoxins are generated during cocultures of HIV-infected monocytes and astroglia[10]. In vivo evidence of 15-LO-dependent lipoxin biosynthesis was obtained in a rat model by transfection of the human 15-LO gene into one of the kidneys. The transfected kidney produced higher amounts of urinary immunoreactive lipoxin $\mathrm{A}_{4}$ compared to the untransfected kidney[11]. 


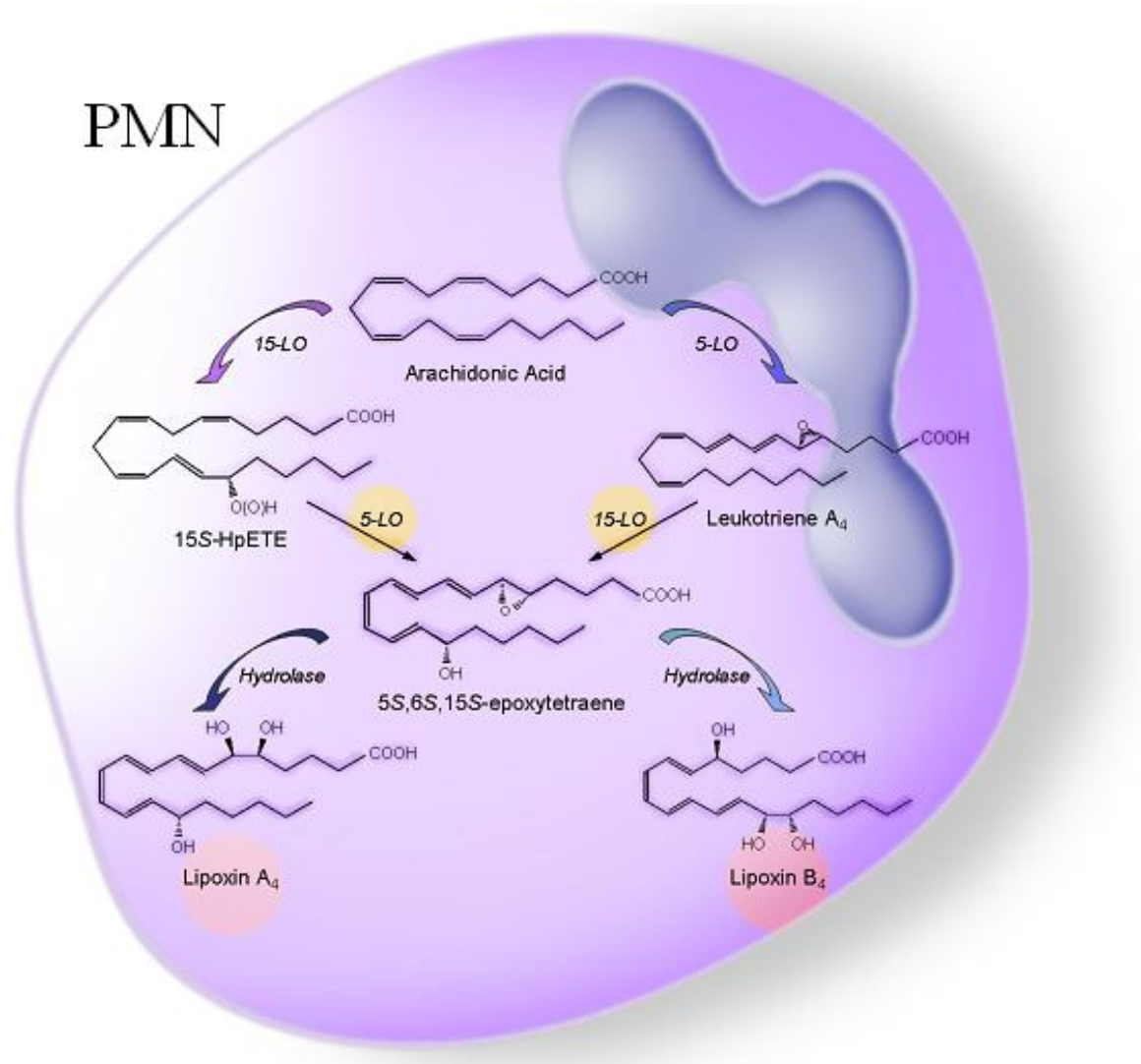

FIGURE 2A. The 5-/15-LO pathway of lipoxin biosynthesis in PMNs.

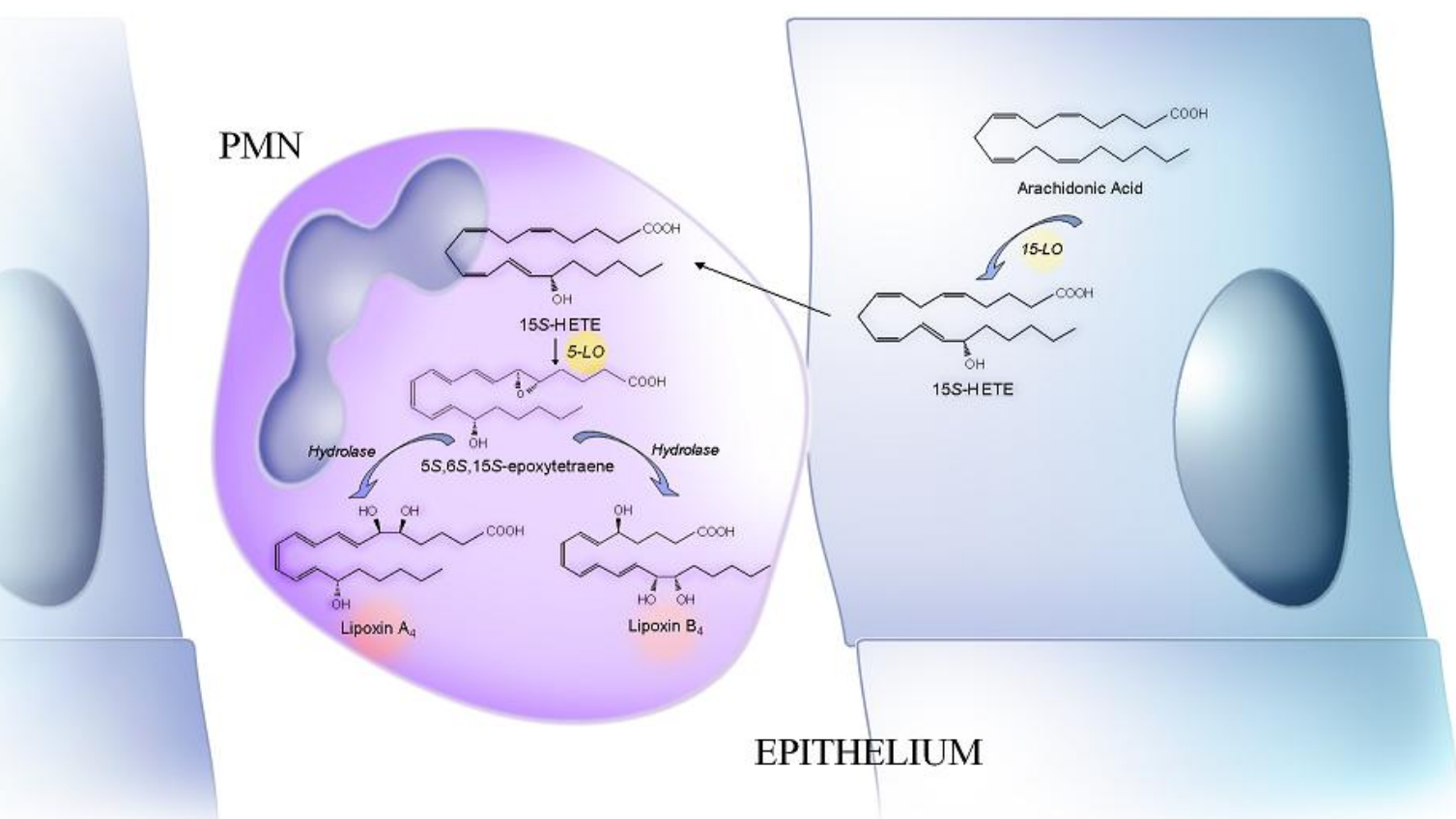

FIGURE 2B. The 5-/15-LO pathway of lipoxin biosynthesis during interactions between PMNs and epithelial cells. 


\section{The 5-/12-LO Pathway}

This pathway was initially characterized in mixed PMN-platelet incubations[12,13,14] and then further elucidated with megakaryocytes[15], 12-LO-transfected cells[15], platelets exposed to leukotriene $\mathrm{A}_{4}$ $\left(\mathrm{LTA}_{4}\right)[16]$, and human platelet recombinant 12-LO incubated with $\mathrm{LTA}_{4}$ in a cell-free system[17]. In this system, 12-LO converted $\mathrm{LTA}_{4}$ into lipoxin $\mathrm{A}_{4}$ and $\mathrm{B}_{4}$ with an apparent $K_{m}$ of $7.9 \pm 0.8 \mu \mathrm{M}$, whereas the calculated $V_{\max }$ was $24.5 \pm 2.5 \mathrm{nmol} / \mathrm{min} / \mathrm{mg}$ of protein[17]. Notably, recombinant 12-LO showed a comparable affinity for arachidonic acid, its main substrate $\left(K_{m}\right.$ of $\left.6.2 \pm 1.8 \mu \mathrm{M}\right)$ [17], suggesting that the lipoxin synthase activity of this enzyme is of primarily biological meaning. In order to generate lipoxins, 12-LO converts $\mathrm{LTA}_{4}$ into a delocalized cation by proton transfer, following hydrogen abstraction from carbon-13 to insert molecular oxygen at carbon-15. The cation is attacked by water at carbon- 6 to give lipoxin $\mathrm{A}_{4}$ and at carbon-14 to yield lipoxin $\mathrm{B}_{4}[15]$ (Fig. 3). 12-LO-governed biosynthesis of lipoxin $\mathrm{B}_{4}$, but not of lipoxin $\mathrm{A}_{4}$, is regulated by mechanism-based inactivation[16,17], suggesting that the 12-LO attack at carbon-14 of the delocalized cation makes the lipoxin $\mathrm{B}_{4}$ formation site inaccessible for further substrate cycling.

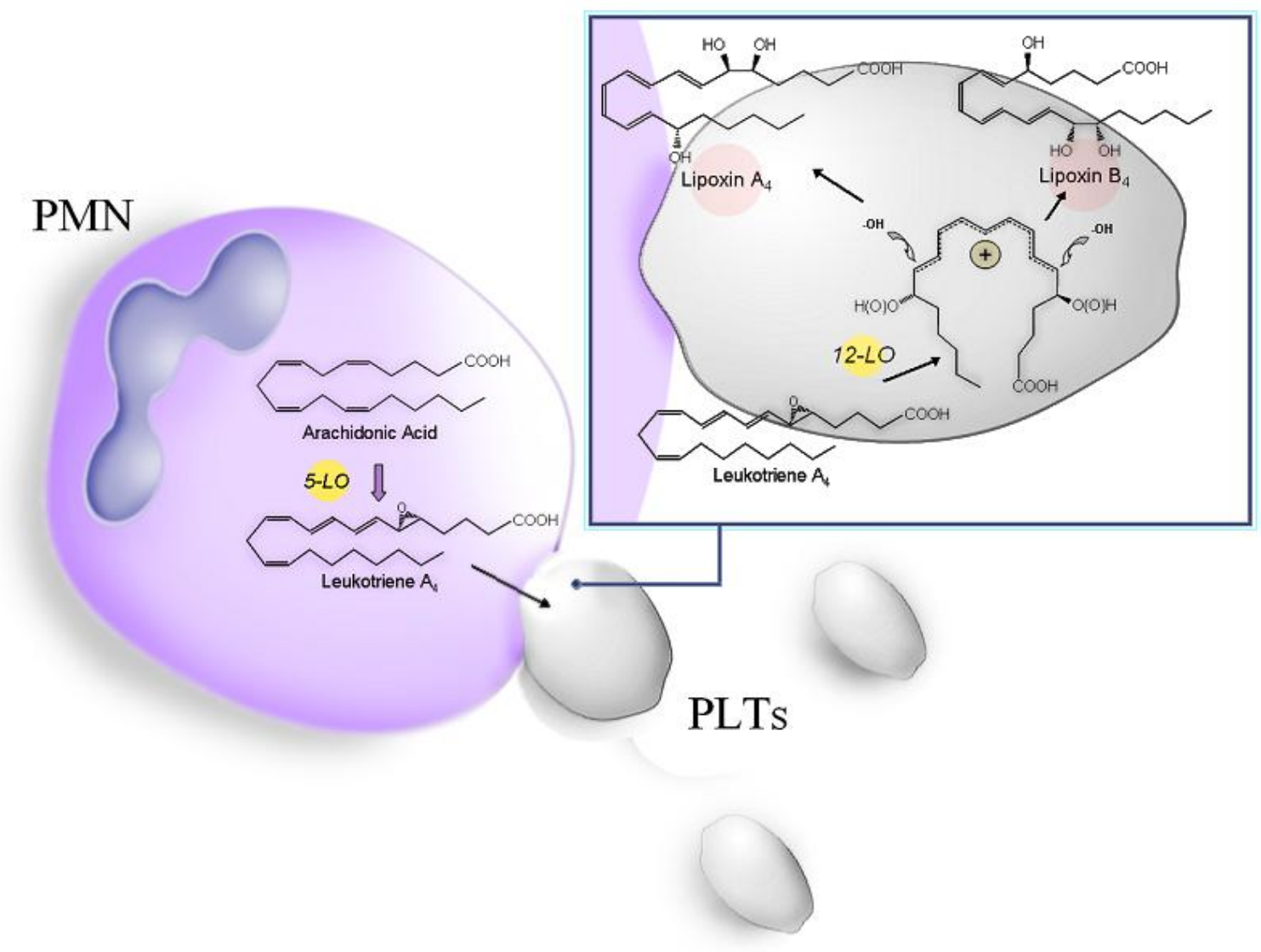

FIGURE 3. The 5-/12-LO pathway of lipoxin biosynthesis during interactions between PMNs and platelets.

In vivo evidence of the 5-/12-LO route of lipoxin generation has been obtained in patients with cardiovascular disease, during coronary angioplasty[18], and in healthy subjects undergoing strenuous physical exercise[19]. In both conditions, enhanced transcellular exchanges between PMNs and platelets have been documented. This route also occurs in trout macrophages to generate lipoxin $\mathrm{A}_{4}[20]$, confirming the evolutionary origin of lipoxins. 


\section{The Origin of the 15-Epi-Lipoxins}

The formation of epi-lipoxins was first detected in mixed incubations of aspirin-treated human umbilical endothelial cells with PMNs[21], which were done on the basis of previous observation that aspirin did not completely suppress COX-2 catalytic activity, but rather redirected it to the transformation of arachidonic acid into 15R-HETE[22]. Among the number of tetraenes formed during these incubations, 15-epi-lipoxin $\mathrm{A}_{4}$ and 15-epi-lipoxin $\mathrm{B}_{4}$ were identified by UV spectroscopy and mass spectrometry. Fifteen-epi-lipoxins were therefore collectively termed aspirin-triggered lipoxins (ATL). Their biosynthesis proceeds through the conversion of $15 R$-HETE by 5-LO to an epoxide intermediate, which, similarly to what occurs during lipoxin formation by 5-/15-LO interactions, is enzymatically converted into 15-epi-lipoxin $\mathrm{A}_{4}$ (ATLa) and 15-epi-lipoxin $\mathrm{B}_{4}$ (Fig. 4). Consistently, ATL were formed by $\mathrm{A}_{23187^{-}}$ stimulated PMN exposed to 15R-HETE[21]. Additional cellular models of ATL formation have been reported, including interactions between PMNs and A459 cells[23], or between hepatocytes and liver cells[24]. In accordance, ATL formation was observed in liver tissue from aspirin-treated rats[24]. ATL and lipoxins can also be formed upon stimulation of whole blood ex vivo[25,26] and their amount is increased in aspirin-tolerant asthmatics compared to aspirin-intolerant asthmatics[26]. Recently, the first evidence of ATL formation in healthy volunteers taking aspirin has been obtained[27]. This was confirmed in a larger randomized clinical trial[28]. Additional circuits of ATL biosynthesis have been unveiled. One is regulated by cytocrome $P-450$, which can be stimulated by aspirin and forms $15 R$ HETE, as intermediate[24]. Another appears to be triggered by pioglitazone and atorvastatin in the rat[29], or by lovastatin via 14,15-epoxyeicosatrienoic acid $(14,15$-EET) generation[30].

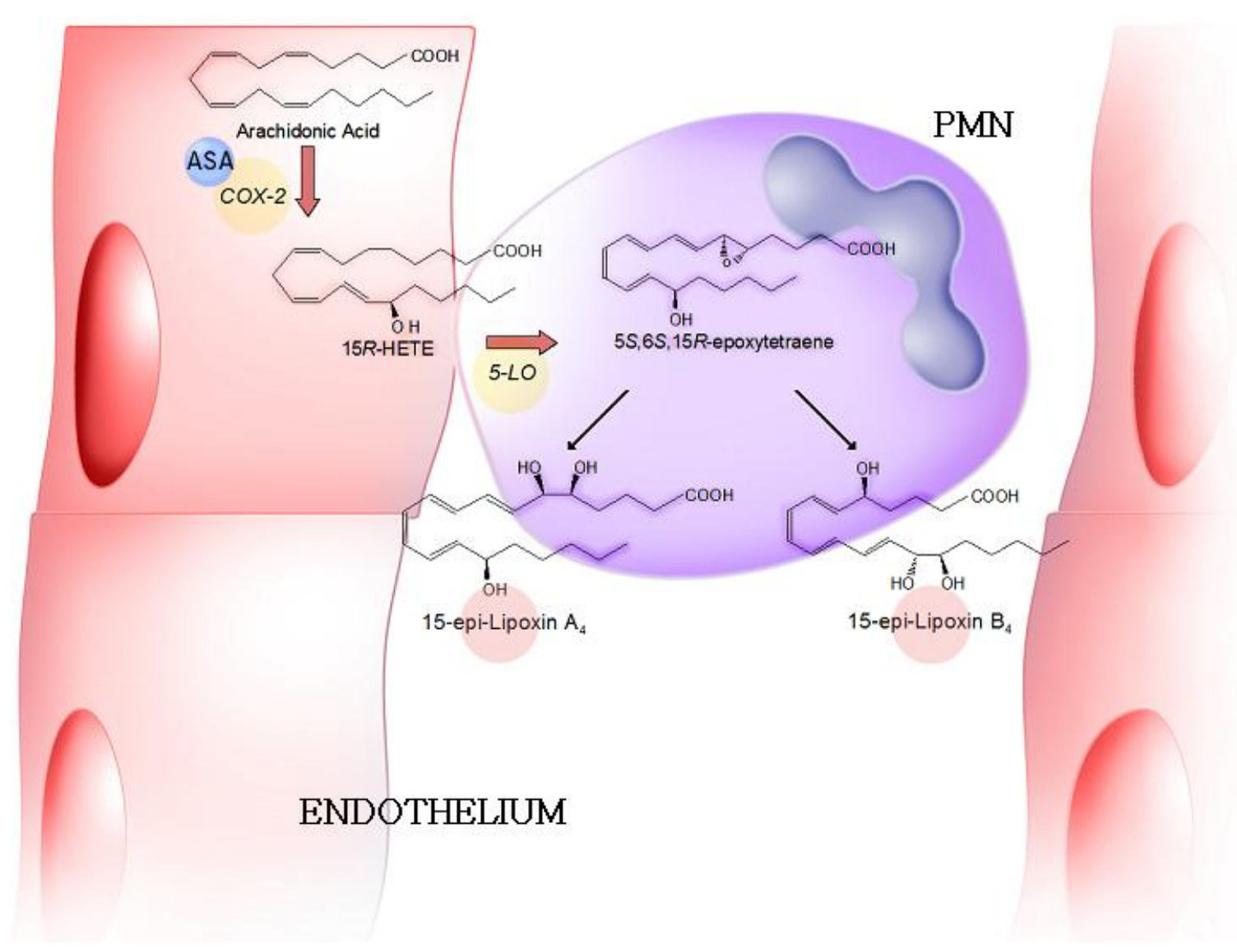

FIGURE 4. ATL biosynthetic pathway during interactions between aspirin-treated endothelial cells and PMNs. 


\section{BIOACTIONS}

\section{The Stable Analogs}

Since their first identification, lipoxins and ATL have displayed an array of biological actions consistent with anti-inflammatory, proresolution profiles. In particular, they block chemotaxis, adherence to microvasculature, transendothelial and transepithelial migration of PMNs[31,32,33,34], and chemotaxis of eosinophils[35,36], while promoting monocyte chemotaxis and nonphlogistic phagocytosis of apoptotic PMNs by macrophages[37,38,39]. In addition, lipoxin $\mathrm{A}_{4}$ and ATLa limit peroxynitrite formation and NF$\mathrm{\kappa B}$ activation in leukocytes[40], PMN azurophilic degranulation[41], the release of the proinflammatory cytokines IL- 6 and IL-8[42], TNF- $\alpha$-induced superoxide anion generation, and IL- $1 \beta$ release by PMNs[43], while they stimulate the release of the antiphlogistic cytokine TGF- $\beta$ in mice[44]. Antiangiogenic and antifibrotic activities of lipoxin $\mathrm{A}_{4}$ and ATLa have also been reported[45,46,47,48,49].

A main limitation for in vivo studies with native lipoxins is represented by their short half-life, since they undergo rapid metabolic inactivation. In the case of lipoxin $\mathrm{A}_{4}$, the main metabolic pathways occur in monocyte/macrophages and involve initial dehydrogenation to 15-oxo-lipoxin $\mathrm{A}_{4}$ by 15hydroxyprostaglandin dehydrogenase (15-PGDH)[50]. The 15-oxo-lipoxin $\mathrm{A}_{4}$ is converted by the 15oxoprostaglandin 13-reductase to 13,14-dihydro-15-oxo-lipoxin $\mathrm{A}_{4}$, which is further metabolized by 15PGDH to yield 13-14-dihydro-lipoxin $\mathrm{A}_{4}$ [51]. Lipoxin $\mathrm{B}_{4}$ undergoes a similar metabolic sequence[52]. $\omega$ Hydroxylation and $\omega$-oxidation pathways have been also reported[53,54,55]. Metabolic inactivation of ATL has been also observed, although 15 -epi-lipoxin $\mathrm{A}_{4}$ appears to be more resistant than lipoxin $\mathrm{A}_{4}$ to dehydrogenation[31].

Because of lipoxin and ATL metabolic inactivation, a number of stable analogs have been synthesized in recent years, mainly focusing on the A series of lipoxins. The first series were designed to minimize 15-PGDH and $\omega$-oxidation-dependent inactivation. Among these were $15 R / S$-methyl-lipoxin $\mathrm{A}_{4}$ and 16-phenoxy-lipoxin $\mathrm{A}_{4}[31]$. These analogs retained receptor-binding affinity and full biological activity in assays of neutrophil transmigration across intestinal epithelial cells[31]. Further improvement in activity and stability was achieved by adding a fluoride to the phenoxy ring of 16-phenoxy- and 15-epi16-phenoxy-lipoxin $\mathrm{A}_{4}$ to yield, respectively, 16-(parafluoro)-phenoxy-lipoxin $\mathrm{A}_{4}$ and 15-epi-16(parafluoro)-phenoxy-lipoxin $\mathrm{A}_{4}$ [56]. Recently, 3-oxa derivatives of 15-epi-16-(parafluoro)-phenoxylipoxin $\mathrm{A}_{4}$ have been synthesized, showing marked resistance to $\beta$-oxidation[57]. More recently, aromatic, pyridin, and benzo analogs have been obtained with enhanced anti-inflammatory properties[58,59,60]. The analogs have been largely used to assess the pathophysiological relevance of lipoxins and ATL in vivo. The large majority of these studies were conducted with lipoxin $\mathrm{A}_{4}$ and ATLa derivatives and showed consistent anti-inflammatory, proresolution properties in a variety of animal models. Although these models have a number of built-in limitations related to species specificity of responses, to the administration of lipoxin $\mathrm{A}_{4}$ prior to the exposure to the pathological agent, with the exception of a very recent study showing proresolution properties of ATLa administered to mice bearing peritonitis[61], and to the modality of disease induction, nevertheless they provide useful indications for future use of lipoxin $\mathrm{A}_{4}$ and ATLa in human disease. The best-characterized models of disease that may benefit from treatment with lipoxin $\mathrm{A}_{4}$ and ATLa are listed below.

\section{DISEASE MODELS}

\section{Respiratory Tract}

\section{Asthma and Allergic Diseases}

Initial studies in asthmatics showed that inhaled native lipoxin $\mathrm{A}_{4}$ attenuated $\mathrm{LTC}_{4}$-induced airway obstruction[62]. It was later demonstrated that lipoxin $\mathrm{A}_{4}$ and ATLa inhibited allergen-induced 
eosinophilic pleurisy in sensitized rats, with a mechanism involving IL-5 and eotaxin production[36]. More recent studies showed bronchodilatory, anti-inflammatory effects of lipoxin $\mathrm{A}_{4}$ and ATLa analogs. For example, ATLa and 3-oxa-15-epi-lipoxin $\mathrm{A}_{4}$ reduced leukocyte recruitment, cysteinyl LTs, IL-4, IL10, and IL-13 in the lung of sensitized mice challenged with ovalbumin[63]. In another study, a lipoxin $\mathrm{A}_{4}$ analog reduced airway hyper-responsiveness, airway inflammation, and eosinophil infiltration, as well as IL-5 and eotaxin levels[64]. Of note, lipoxin $\mathrm{A}_{4}$ may play a key role in the homeostasis of airway epithelium since it up-regulates the expression of the tight junction proteins zonula occludens-1, claudin1 , and occludin, sustaining transepithelial electrical resistance[65]. Thus, lipoxin $\mathrm{A}_{4}$ may also promote epithelial repair in the airway.

Consistent with the protective action of endogenous lipoxins and ATL, patients with asthma or allergic rhinitis display reduced levels and biosynthetic potential of these eicosanoids[66].

\section{Acute Lung Injury}

Evidence is accumulating of lipoxin $\mathrm{A}_{4}$ and ATLa protection of acid-induced acute lung injury. Mechanisms are related to the modulation of the expression of the lipoxin $\mathrm{A}_{4}$ receptor, the inhibition of the release of inflammatory cytokines, and neutrophil apoptosis[67,68]. In addition, benzolipoxin analogs protected lungs from hindlimb ischemia-reperfusion injury of the lung[60]. In another study, 15-epi-16(parafluoro)-phenoxy lipoxin $\mathrm{A}_{4}$ protected the mice lung from LPS-induced acute lung injury, with a heme-oxygenase-1-dependent mechanism[69]. Finally, ATLa prevented inflammatory and fibrotic reactions in bleomycin-induced pulmonary fibrosis, improving pulmonary mechanics and survival[49].

\section{Cystic Fibrosis}

Neutrophilic lung disease is a trademark of cystic fibrosis (CF). Reduced levels of lipoxin $\mathrm{A}_{4}$ in bronchoalveolar lavage fluid from CF patients was recently detected[70], suggesting that the sustained inflammatory response in CF may be related to impairments of resolution pathways. Consistently, 15-epi16-(parafluoro)-phenoxy-lipoxin $\mathrm{A}_{4}$ blocked Pseudomonas aeruginosa-induced IL-8 secretion and PMN recruitment in mice[70]. This ATLa analog also ameliorated disease progression in mice exposed to $P$. aeruginosa[70]. Notably, antibiotics increased lipoxin $\mathrm{A}_{4}$ and decreased IL-8 levels in CF sputum[71].

\section{Joints}

\section{Rheumatoid Arthritis}

The observation that lipoxin $\mathrm{A}_{4}$ inhibits proinflammatory responses of human synovial fibroblasts, i.e., matrix metalloproteinase and cytokine release[42], suggests that lipoxins and ATL may be beneficial in rheumatoid arthritis (RA). Synovial tissues from RA patients exhibited enhanced expression of the lipoxin $\mathrm{A}_{4}$ receptor compared to patients with osteoarthritis[72]. Likewise, synovial fluids from RA patients showed higher concentrations of lipoxin $\mathrm{A}_{4}$ and ATL[72]. Thus, up-regulation of the lipoxin $\mathrm{A}_{4} /$ lipoxin $\mathrm{A}_{4}$ receptor dyad appears to represent a response to injury mechanism in RA. Whether it may convey anti-inflammatory signaling remains to be determined. The relevance of the lipoxin $\mathrm{A}_{4}$ receptor within the context of RA is underscored by the recent observation that BML-111, a lipoxin $\mathrm{A}_{4}$ receptor agonist, reduced disease activity scores and joint destruction in a collagen-induced arthritis mouse model[73]. Although further evidence is needed, collectively, these results provide the background for the potential use of lipoxin $\mathrm{A}_{4}$ and ATLa derivatives in RA. 


\section{Gastrointestinal Apparatus}

\section{Stomach}

Gastrolesivity represents a main drawback to chronic administration of aspirin. ATL biosynthesis by the rat gastric mucosa following aspirin administration has been reported[74], suggesting that ATL formation by aspirin-acetylated COX-2 may represent a mechanism of gastric adaptation to aspirin. Thus, it may be reasoned that aspirin-related gastric damage occurs when the buffering capability of ATL becomes insufficient. Indeed, lipoxin $\mathrm{A}_{4}$ protected the rat gastric mucosa from aspirin-induced damage[75]. In healthy humans, aspirin enhanced ATLa urinary levels, which were suppressed by selective COX-2 inhibitors (Coxibs)[27], underlying the potential increased risk of gastric damage when aspirin is coadministered with Coxibs. However, in a more recent study with a cohort of 24 patients affected by ischemic heart disease in association with osteoarthritis, chronically treated with aspirin, the administration of selective or nonselective COX inhibitors did not significantly change urinary ATL levels[76], indicating that in this specific clinical setting, other factors may influence ATL excretion. On the other hand, evaluation of gastric ATLa production may be more informative regarding the protective role of this eicosanoid in protection from gastric damage induced by COX inhibitors, since urinary ATLa levels do not necessarily reflect ATLa biosynthesis within the gastric mucosa. Lipoxin $\mathrm{A}_{4}$ protection of gastric damage induced by ethanol, sodium salicylate, or ischemia reperfusion has been reported in rats[77,78], extending the array of etiopathogenetic events that can benefit from lipoxin $\mathrm{A}_{4}$ or ATLa administration.

\section{Bowel}

An early study showed that lipoxin $\mathrm{A}_{4}$ limited neutrophil transmigration across the intestinal epithelium[32] and protected, as well as ATLa, colonocytes from TNF- $\alpha$-induced apoptosis[79], suggesting that lipoxins and ATL may be protective during intestinal inflammatory disorders. This hypothesis was challenged and proved to be correct in a number of studies. Lipoxin analogs attenuated dextran sodium sulfate-induced colitis[80]. $\beta$-Oxidation-resistant lipoxin $\mathrm{A}_{4}$ analogs ameliorated hapteninduced colitis[81]. These effects are likely to be receptor mediated, since the intestinal epithelium expresses the lipoxin $\mathrm{A}_{4}$ receptor[82], which is preferentially localized on the basolateral surface of polarized cells[83]. Remarkably, ATLa showed significant proresolution activity when administered to mice bearing peritonitis[61].

Lipoxin $\mathrm{A}_{4}$ inhibition of NF- $\mathrm{BB}$ activation in intestinal epithelial cells has been recently reported[84], providing further insight into the molecular mechanism of lipoxin $\mathrm{A}_{4}$ protective action in gastrointestinal inflammatory disorders.

\section{Urinary Tract}

The involvement of lipoxins and ATL in renal pathophysiology has been established by a number of studies in vitro and in vivo. In mesangial cells, lipoxin $\mathrm{A}_{4}$ antagonized a number of proinflammatory, hemodynamic, fibrotic responses, such as LT-dependent decrease in filtration rate[85] and neutrophil adhesion[86]; PDGF-induced proliferation[87,88], via inhibition of Akt/PKB signaling[89] and profibrotic gene expression[48]; and connective tissue growth factor-stimulated chemokine production[90]. In vivo, 15-epi-16-(parafluoro)-phenoxy-lipoxin $\mathrm{A}_{4}$ displayed protective properties in a rat model of ischemic acute renal failure[91]. Consistently, transcriptomic analysis during murine ischemia-reperfusion injury revealed that this analog regulated the expression of a number of cytokines, growth factors, adhesion molecules, and proteases, with a renoprotective profile[92]. 
Further support to the renoprotective activity of lipoxin $\mathrm{A}_{4}$ and ATLa is provided by the observation of lipoxin $\mathrm{A}_{4}$ biosynthesis and function maintenance following rat kidney transfection with 15-LO in experimental antibody-induced glomerulonephritis[11].

\section{Eye}

Endogenous generation of lipoxin $\mathrm{A}_{4}$ by mouse corneas has been recently observed[93]. Topical treatment with lipoxin $\mathrm{A}_{4}$ promoted corneal re-epithelialization and attenuated thermal injury[94], with a mechanism involving heme-oxygenase-1 up-regulation[95]. In a rat model of endotoxin-induced uveitis, topical lipoxin $\mathrm{A}_{4}$ reduced the inflammatory infiltrate and the protein leakage into the aqueous humor. It also inhibited accumulation of IL-1 $\beta$ and TNF- $\alpha$, as well as NF- $\kappa B$ and c-Jun activation[96].

ATLa attenuated suture- or micropellet-induced corneal neovascularization in mice, reducing neutrophil and macrophage and lowering mRNA levels of TNF- $\alpha$, IL-1 $\alpha$, IL-1 $\beta$, VEGF-A, VEGF-C, and VEGFR2[97]. Consistently, topical lipoxin $\mathrm{A}_{4}$ rescued 15-LO knockout mice from suture-induced exacerbated angiogenesis[98].

Together, these results provide substantial support to therapeutic use of lipoxin $\mathrm{A}_{4}$ and ATL analogs in selected diseases of the eye.

\section{Vascular Disease}

Lipoxins regulate key pathways of vascular homeostasis. Early studies showed lipoxin stimulation of prostacyclin secretion by endothelial cells[99] and vasorelaxant effects[100], indicating that lipoxins may regulate the vascular tone. The regulatory effect of ATLa on nitric oxide release was also reported[101], although no evidence of direct lipoxin impact on NO biosynthesis has yet been presented. Consistent with a vasoprotective profile, ATLa inhibited generation of reactive oxygen species by endothelial cells[102]. Best characterized is the impact of lipoxins and ATL on angiogenic pathways. Modulation of endothelial cell proliferation, as well as VEGF and VEGF receptor expression by lipoxin $\mathrm{A}_{4}$ and ATLa, have been described in a variety of experimental settings as part of an anti-inflammatory response[45,46,97,103,104].

Recently, the hypothesis that endogenous anti-inflammatory, proresolution circuits, including lipoxin and ATL biosynthesis, may be altered in atherosclerosis has been put forward[105]. This model of disease, as well as vasculitis and other degenerative vascular disease, may represent interesting fields of investigation of lipoxin and ATL functions within the context of vascular pathobiology.

\section{Infectious Disease}

\section{Parasite}

Lipoxin $\mathrm{A}_{4}$ appears to regulate IL-12 generation by dendritic cells exposed to a Toxoplasma gondii extract[106]. Induction of lipoxin $\mathrm{A}_{4}$ biosynthesis by $T$. gondii in vivo has been reported[107]. This appears to represent a host defense mechanism, since the administration of 15-epi-16-(parafluoro)phenoxy-lipoxin $\mathrm{A}_{4}$ prevented postinfection mortality of 5-LO knockout mice[106]. Consistently, plant 15-LO generated endogenous lipoxin $\mathrm{A}_{4}$ and suppressed $T$. gondii-induced production of IL-12 by splenic dendritic cells[108].

\section{TBC}

Mice infected with Mycobacterium tuberculosis produced high levels of lipoxin $\mathrm{A}_{4}$, which were substantially reduced in 5-LO knockout animals[109]. Administration to these mice of 15-epi-16- 
(parafluoro)-phenoxy-lipoxin $\mathrm{A}_{4}$ significantly reduced bacterial growth in the lung as well as IFN- $\gamma$ production by splenocytes. Macrophages are likely to represent a main source of lipoxin $\mathrm{A}_{4}$ upon $M$. tuberculosis infection[110].

\section{Periodontitis}

Lipoxin $\mathrm{A}_{4}$ analogs inhibited leukocyte recruitment elicited by Phorphyromonas gingivalis in a murine air pouch model[111]. Remarkably, topical application of 15-epi-16-(parafluoro)-phenoxy-lipoxin $\mathrm{A}_{4}$ drastically reduced leukocyte infiltration, bone loss, and inflammation in a rabbit model of acute periodontitis[112].

\section{Reperfusion Injury}

Lipoxin and ATL protection from reperfusion injury is not restricted to the renal district. In fact, ATLa inhibited PMN infiltrates in the lung following hindlimb ischemia reperfusion[113], suggesting that lipoxins and ATL may antagonize stress responses, such as those observed in perioperative medicine. Along these lines, lipoxin $\mathrm{A}_{4}$ and ATLa reduced the expression of the ischemia-induced chemokine and cytokine-induced neutrophil chemoattractant (CINC)-1 in rat liver[114].

Furthermore, in a rat model of transient focal cerebral ischemia, induced by middle cerebral artery occlusion, intracerebroventricular administration of a lipoxin $\mathrm{A}_{4}$ analog reduced infarction volume and improved neurological dysfunctions[115]. Down-regulation of proinflammatory cytokines TNF- $\alpha$ and IL$1 \beta$, as well as of NF- $\mathrm{BB}$, and up-regulation of anti-inflammatory cytokines IL-10 and TGF- $\beta_{1}$ in the ischemic brain were observed[116]. The lipoxin $\mathrm{A}_{4}$-IL-10 axis seems to play a relevant role in protection from reperfusion injury, since lipoxin $\mathrm{A}_{4}$ failed to reduce inflammation and tissue damage in IL-10deficient mice[116].

A schematic representation of diseases that may benefit from treatment with lipoxin $\mathrm{A}_{4}$ and ATLa is reported in Fig. 5.

\section{FPR2/ALX, THE LIPOXIN A RECEPTOR}

Lipoxin $\mathrm{A}_{4}$, ATLa, and analogs anti-inflammatory functions are achieved through the activation of a specific receptor, spanning seven-transmembrane domains and belonging to the family of chemotactic receptors[117,118]. This receptor, initially termed FPRL1, has been recently renamed FPR2/ALX[119]. A comprehensive description of FPR2/ALX characteristics is beyond the scope of this review. Nevertheless, it is worth mentioning that this receptor is highly expressed in cells of the immune inflammatory response, i.e., PMNs, monocytes, lymphocytes, and endothelial cells, and that in addition to lipoxin $\mathrm{A}_{4}$, ATLa, and their stable analogs, it is recognized by a number of peptides, including the anti-inflammatory annexin A1 and the proinflammatory serum amyloid A (reviewed in Romano et al.[120]). Notably, the potent anti-inflammatory resolvin D1 is a partial agonist for this receptor[121], suggesting complex interactions among anti-inflammatory receptors and their agonists. Studies with transgenics overexpressing Fpr2, the mouse hortholog of FPR2/ALX in myeloid cells or with Fpr2 knocked out[122,123], conclusively proved the predominant anti-inflammatory properties of this receptor, which thus may represent a potential pharmacological target for treatment of inflammatory disorders. 


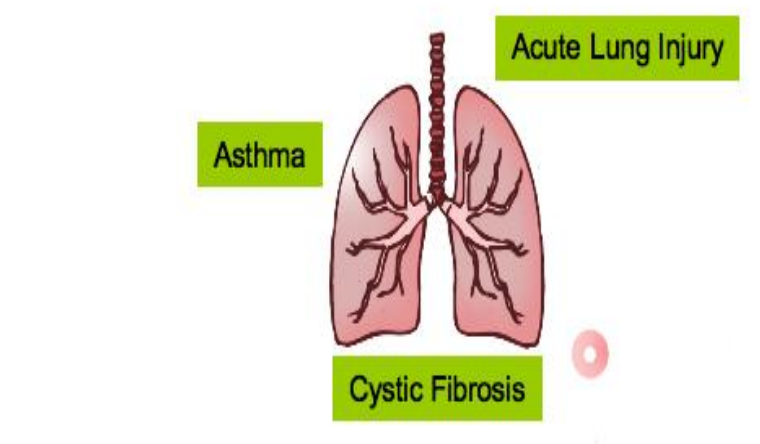

Rheumatoid Athritis

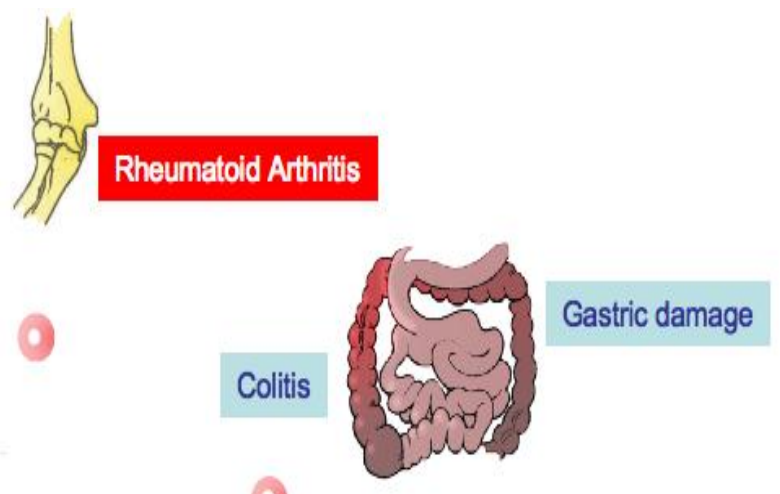

\section{Comeal Injury}
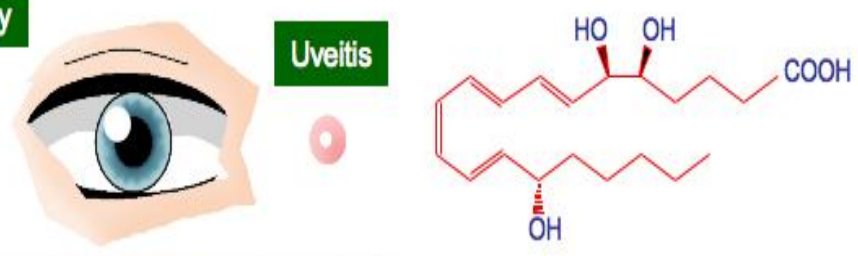

Suture-induced neovascularization
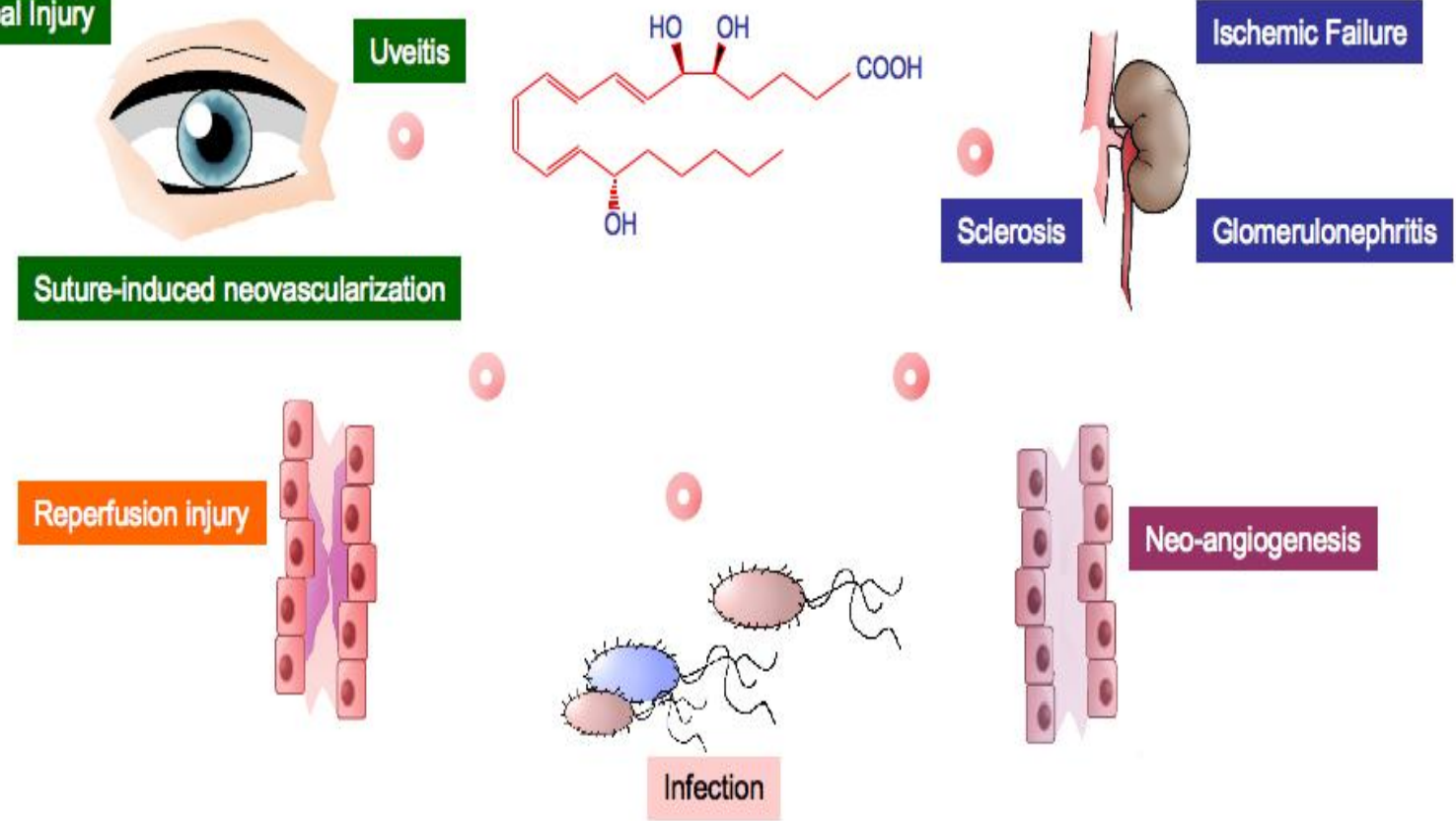

Neo-angiogenesis

FIGURE 5. Clinical settings where administration of lipoxin $\mathrm{A}_{4}$ or ATLa could be beneficial.

\section{CONCLUSIONS}

Evidence that lipoxin and ATL exert potent anti-inflammatory, proresolution bioactions has been consolidated over the years. The bioactions and signaling of these eicosanoids have been largely elucidated, although the list is continuously growing. The significant impact of lipoxin $\mathrm{A}_{4}$, ATLa, and their stable analogs in a large variety of animal studies and in vitro models of disease is suggestive of the potential use of these compounds in human therapy. In this respect, in a document dated March 17, 2010, Bayer has announced to investors that lipoxin is in phase I development for inflammatory bowel disease. Additional human studies are now awaited to complete the transition of these eicosanoids from bench to bedside.

\section{ACKNOWLEDGMENTS}

The author wishes to tank Stefano Lattanzio for excellent graphic assistance. 


\section{REFERENCES}

1. Serhan, C.N., Hamberg, M., and Samuelsson, B. (1984) Trihydroxytetraenes: a novel series of compounds formed from arachidonic acid in human leukocytes. Biochem. Biophys. Res. Commun. 118, 943-949.

2. Serhan, C.N., Hamberg, M., and Samuelsson, B. (1984) Lipoxins: novel series of biologically active compounds formed from arachidonic acid in human leukocytes. Proc. Natl. Acad. Sci. U. S. A. 81, 5335-5339.

3. Serhan, C.N., Nicolaou, K.C., Webber, S.E., Veale, C.A., Dahlen, S.E., Puustinen, T.J., and Samuelsson, B. (1986) Lipoxin A. Stereochemistry and biosynthesis. J. Biol. Chem. 261, 16340-16345.

4. Serhan, C.N., Hamberg, M., Samuelsson, B., Morris, J., and Wishka, D.G. (1986) On the stereochemistry and biosynthesis of lipoxin B. Proc. Natl. Acad. Sci. U. S. A. 83, 1983-1987.

5. Romano, M. (2006) Lipid mediators: lipoxin and aspirin-triggered 15-epi-lipoxins. Inflamm. Allergy Drug Targets $\mathbf{5}$, 81-90.

6. Chavis, C., Vachier, I., Chanez, P., Bousquet, J., and Godard, P. (1996) 5(S),15(S)-dihydroxyeicosatetraenoic acid and lipoxin generation in human polymorphonuclear cells: dual specificity of 5-lipoxygenase towards endogenous and exogenous precursors. J. Exp. Med. 183, 1633-1643.

7. Serhan, C.N., Hirsch, U., Palmblad, J., and Samuelsson, B. (1987) Formation of lipoxin A by granulocytes from eosinophilic donors. FEBS Lett. 217, 242-246.

8. Levy, B.D., Romano, M., Chapman, H.A., Reilly, J.J., Drazen, J., and Serhan, C.N. (1993) Human alveolar macrophages have 15-lipoxygenase and generate 15(S)-hydroxy-5,8,11-cis-13-trans-eicosatetraenoic acid and lipoxins. J. Clin. Invest. 92, 1572-1579.

9. Edenius, C., Kumlin, M., Bjork, T., Anggard, A., and Lindgren, J.A. (1990) Lipoxin formation in human nasal polyps and bronchial tissue. FEBS Lett. 272, 25-28.

10. Genis, P., Jett, M., Bernton, E.W., Boyle, T., Gelbard, H.A., Dzenko, K., Keane, R.W., Resnick, L., Mizrachi, Y., Volsky, D.J., Epstein, L.G., and Gendelman, H.E. (1992) Cytokines and arachidonic metabolites produced during human immunodeficiency virus (HIV)-infected macrophage-astroglia interactions: implications for the neuropathogenesis of HIV disease. J. Exp. Med. 176, 1703-1718.

11. Munger, K.A., Montero. A., Fukunaga, M., Uda, S., Yura, T., Imal, E., Kaneda, Y., Valdlvielso, J.M., and Badr, K.F. (1999) Transfection of rat kidney with human 15-lipoxygenase suppresses inflammation and preserves function in experimental glomerulonephritis. Proc. Natl. Acad. Sci. U. S. A. 96, 13375-13380.

12. Edenius, C., Haeggstrom, J., and Lindgren, J.A. (1988) Transcellular conversion of endogenous arachidonic acid to lipoxins in mixed human platelet-granulocyte suspensions. Biochem. Biophys. Res. Commun. 157, 801-807.

13. Serhan, C.N. and Sheppard, K.A. (1990) Lipoxin formation during human neutrophil-platelet interactions. Evidence for the transformation of leukotriene A4 by platelet 12-lipoxygenase in vitro. J. Clin. Invest. 85, 772-780.

14. Fiore, S. and Serhan, C.N. (1990) Formation of lipoxins and leukotrienes during receptor-mediated interactions of human platelets and recombinant human granulocyte/macrophage colony-stimulating factor-primed neutrophils. $J$. Exp. Med. 172, 1451-1457.

15. Sheppard, K.A., Greenberg, S.M., Funk, C.D., Romano, M., and Serhan, C.N. (1992) Lipoxin generation by human megakaryocyte-induced 12-lipoxygenase. Biochim. Biophys. Acta 1133, 223-234.

16. Romano, M. and Serhan, C.N. (1992) Lipoxin generation by permeabilized human platelets. Biochemistry 31, 82698277.

17. Romano, M., Chen, X.S., Takahashi, Y., Yamamoto, S., Funk, C.D., and Serhan, C.N. (1993) Lipoxin synthase activity of human platelet 12-lipoxygenase. Biochem. J. 296, 127-133.

18. Brezinski, D.A., Nesto, R.W., and Serhan, C.N. (1992) Angioplasty triggers intracoronary leukotrienes and lipoxin A4. Impact of aspirin therapy. Circulation 86, 56-63.

19. Gangemi, S., Luciotti, G., D’Urbano, E., Mallamace, A., Santoro, A., Bellinghieri, G., Davì, G., and Romano, M. (2003) Physical exercise increases urinary excretion of lipoxin A4 and related compounds. J. Appl. Physiol. 94, 22372240.

20. Rowley, A.F., Lloyd-Evans, P., Barrow, S., and Serhan, C.N. (1994) Lipoxin biosynthesis by trout macrophages involves the formation of epoxide intermediates. Biochemistry 33, 856-863.

21. Claria, J. and Serhan, C.N. (1995) Aspirin triggers previously undescribed bioactive eicosanoids by human endothelial cell-leukocyte interactions. Proc. Natl. Acad. Sci. U. S. A. 92, 9475-9479.

22 . Holzman, M.J., Turk, J., and Shornick, I.P. (1992) Identification of a pharmacologically distinct prostaglandin H synthase in cultured epithelial cells. J. Biol. Chem. 267, 21438-21445.

23. Claria, J., Lee, M.H., and Serhan, C.N. (1996) Aspirin-triggered lipoxins (15-epi-LX) are generated by the human lung adenocarcinoma cell line (A549)-neutrophil interactions and are potent inhibitors of cell proliferation. Mol. Med. 2, 583-596.

24. Titos, E., Chiang, N., Serhan, C.N., Romano, M., Gaya, J., Pueyo, G., and Claria, J. (1999) Hepatocytes are a rich source of novel aspirin-triggered 15-epi-lipoxin A(4). Am. J. Physiol. 277, C870-877.

25. Brezinski, D. and Serhan, C.N. (1991) Characterization of lipoxins by combined gas chromatography and electroncapture negative ion chemical ionization mass spectrometry: formation of lipoxin A4 by stimulated human whole blood. Biol. Mass Spectr. 20, 45-52. 
26. Sanak, M., Levy, B.D., Clish, C.B., Chiang, N., Gronert, K., Mastalerz, L., Serhan, C.N., and Szczeklik, A. (2000) Aspirin-tolerant asthmatics generate more lipoxins than aspirin-intolerant asthmatics. Eur. Respir. J. 16, 44-49.

27. Fiorucci, S., Santucci, L., Wallace, J.L., Sardina, M., Romano, M., Del Soldato, P., and Morelli, A. (2003) Interaction of a selective cyclooxygenase-2 inhibitor with aspirin and NO-releasing aspirin in the human gastric mucosa. Proc. Natl. Acad. Sci. U. S. A. 100, 10937-109341.

28. Chiang, N., Bermudez, E.A., Ridker, P.M., Hurwitz, S., and Serhan, C.N. (2004) Aspirin triggers antiinflammatory 15-epi-lipoxin A4 and inhibits thromboxane in a randomized human trial. Proc. Natl. Acad. Sci. U. S. A. 101, 1517815183.

29. Birnbaum, Y., Ye, Y., Lin, Y., Freeberg, S.Y., Nishi, S.P., Martinez, J.D., Huang, M.H., Uretsky, B.F., and PerezPolo, .JR. (2006) Augmentation of myocardial production of 15-epi-lipoxin-a4 by pioglitazone and atorvastatin in the rat. Circulation 114, 929-935.

30. Planagumà, A., Pfeffer, M.A., Rubin, G., Croze, R., Uddin, M., Serhan, C.N., and Levy, B.D. (2010) Lovastatin decreases acute mucosal inflammation via 15-epi-lipoxin A(4) Mucosal Immunol. 3, 270-279.

31. Serhan, C.N., Maddox, J.F., Petasis, N.A., Akritopoulou-Zanze, I., Papayianni, A., Brady, H.R., Colgan, S.P., and Madara, J.L. (1995) Design of lipoxin A4 stable analogs that block transmigration and adhesion of human neutrophils. Biochemistry 34, 14609-14615.

32. Colgan, S.P., Serhan, C.N., Parkos, C.A., Delp-Archer, C., and Madara, J.L. (1993) Lipoxin A4 modulates transmigration of human neutrophils across intestinal epithelial monolayers. J. Clin. Invest. 92, 75-82.

33. Scalia, R., Gefen, J., Petasis, N.A., Serhan, C.N., and Lefer, A.M. (1997) Lipoxin A4 stable analogs inhibit leukocyte rolling and adherence in the rat mesenteric microvasculature: role of P-selectin. Proc. Natl. Acad. Sci. U. S. A. 94, 9967-9972.

34. Fierro, I.M., Colgan, S.P., Bernasconi, G., Petasis, N.A., Clish, C.B., Arita, M., and Serhan, C.N. (2003) Lipoxin A4 and aspirin-triggered 15-epi-lipoxin A4 inhibit human neutrophil migration: comparisons between synthetic 15 epimers in chemotaxis and transmigration with microvessel endothelial cells and epithelial cells. J. Immunol. 170, 2688-2694.

35. Soyombo, O., Spur, B.W., and Lee, T.H. (1994) Effects of lipoxin A4 on chemotaxis and degranulation of human eosinophils stimulated by platelet-activating factor and N-formyl-L-methionyl-L-leucyl-L-phenylalanine. Allergy 49, 230-234.

36. Bandeira-Melo, C., Bozza, P.T., Diaz, B.L., Cordeiro, R.S., Jose, P.J., Martins, M.A., and Serhan, C.N. (2000) Cutting edge: lipoxin (LX) A4 and aspirin-triggered 15-epi-LXA4 block allergen-induced eosinophil trafficking. $J$. Immunol. 164, 2267-2271.

37. Maddox, J.F. and Serhan, C.N. (1996) Lipoxin A4 and B4 are potent stimuli for human monocyte migration and adhesion: selective inactivation by dehydrogenation and reduction. J. Exp. Med. 183, 137-146.

38. Romano, M., Maddox, J.F., and Serhan, C.N. (1996) Activation of human monocytes and the acute monocytic leukemia cell line (THP-1) by lipoxins involves unique signaling pathways for lipoxin A4 versus lipoxin B4: evidence for differential Ca2+ mobilization. J. Immunol. 157, 2149-2154.

39. Godson, C., Mitchell, S., Harvey, K., Petasis, N.A., Hogg, N., and Brady, H.R. (2000) Cutting edge: lipoxins rapidly stimulate nonphlogistic phagocytosis of apoptotic neutrophils by monocyte-derived macrophages. J. Immunol.164, $1663-1667$.

40. Jozsef, L., Zouki, C., Petasis, N.A., Serhan, C.N., and Filep, J.G. (2002) Lipoxin A4 and aspirin-triggered 15-epilipoxin A4 inhibit peroxynitrite formation, NF-kappa B and AP-1 activation, and IL-8 gene expression in human leukocytes. Proc. Natl. Acad. Sci. U. S. A. 99, 13266-13271.

41. Gewirtz, A.T., Fokin, V.V., Petasis, N.A., Serhan, C.N., and Madara, J.L. (1999) LXA4, aspirin-triggered 15-epiLXA4, and their analogs selectively downregulate PMN azurophilic degranulation. Am. J. Physiol. 276, C988-994.

42. Sodin-Semrl, S., Taddeo, B., Tseng, D., Varga, J., and Fiore, S. (2000) Lipoxin A4 inhibits IL-1 beta-induced IL-6, IL-8, and matrix metalloproteinase-3 production in human synovial fibroblasts and enhances synthesis of tissue inhibitors of metalloproteinases. J. Immunol. 164, 2660-2666.

43. Hachicha, M., Pouliot, M., Petasis, N.A., and Serhan, C.N. (1999) Lipoxin (LX)A4 and aspirin-triggered 15-epiLXA4 inhibit tumor necrosis factor 1alpha-initiated neutrophil responses and trafficking: regulators of a cytokinechemokine axis. J. Exp. Med. 189, 1923-1930.

44. Bannenberg, G.L., Chiang, N., Ariel, A., Arita, M., Tjonahen, E., Gotlinger, K.H., Hong, S., and Serhan, C.N. (2005) Molecular circuits of resolution: formation and actions of resolvins and protectins. J. Immunol. 174, 4345-4355.

45. Cezar-de-Mello, P.F., Vieira, A.M., Nascimento-Silva, V., Villela, C.G., Barja-Fidalgo, C., and Fierro, I.M. (2008) ATL-1, an analogue of aspirin-triggered lipoxin A4, is a potent inhibitor of several steps in angiogenesis induced by vascular endothelial growth factor. Br. J. Pharmacol. 153, 956-965.

46. Baker, N., O'Meara, S.J., Scannell, M., Maderna, P., and Godson, C. (2009) Lipoxin A4: anti-inflammatory and antiangiogenic impact on endothelial cells. J. Immunol. 182, 3819-3826.

47. Leedom, A.J., Sullivan, A.B., Dong, B., Lau, D., and Gronert, K. (2010) Endogenous LXA4 circuits are determinants of pathological angiogenesis in response to chronic injury. Am. J. Pathol. 176, 74-84.

48. Rodgers, K., McMahon, B., Mitchell, D., Sadlier, D., and Godson, C. (2005) Lipoxin A4 modifies platelet-derived growth factor-induced pro-fibrotic gene expression in human renal mesangial cells. Am. J. Pathol. 167, 683-694. 
49. Martins, V., Valença, S.S., Farias-Filho, F.A., Molinaro, R., Simões, R.L., Ferreira, T.P., e Silva, P.M., Hogaboam, C.M., Kunkel, S.L., Fierro, I.M., Canetti, C., and Benjamim, C.F. (2009) ATLa, an aspirin-triggered lipoxin A4 synthetic analog, prevents the inflammatory and fibrotic effects of bleomycin-induced pulmonary fibrosis. $J$. Immunol. 182, 5374-5381.

50. Serhan, C.N., Fiore, S., Brezinski, D.A., and Lynch, S. (1993) Lipoxin A4 metabolism by differentiated HL-60 cells and human monocytes: conversion to novel 15-oxo and dihydro products. Biochemistry 32, 6313-6319.

51. Clish, C.B., Levy, B.D., Chiang, N., Tai, H.-H., and Serhan, C.N. (2000) Oxidoreductases in lipoxin A4 metabolic inactivation: a novel role for 15-onoprostaglandin 13-reductase/leukotriene B4 12-hydroxydehydrogenase in inflammation. J. Biol. Chem. 275, 25372-25380.

52. Maddox, J.F. and Serhan, C.N. (1996) Lipoxin A4 and B4 are potent stimuli for human monocyte migration and adhesion: selective inactivation by dehydrogenation and reduction. J. Exp. Med. 183, 137-146.

53. Sumimoto, H., Isobe, R., Mizukami, Y., and Minakami, S. (1993) Formation of a novel 20-hydroxylated metabolite of lipoxin A4 by human neutrophil microsomes. FEBS Lett. 315, 205-210.

54. Mizukami, Y., Sumimoto, H., Isobe, R., and Minakami, S. (1993) Omega-hydroxylation of lipoxin B4 by human neutrophil microsomes: identification of omega-hydroxy metabolite of lipoxin B4 and catalysis by leukotriene B4 omega-hydroxylase (cytochrome P-450LTB omega). Biochim. Biophys. Acta 1168, 87-93.

55. Mizukami, Y., Sumimoto, H., Isobe, R., Minakami, S., and Takeshige, K. (1994) omega-Oxidation of lipoxin B4 by rat liver. Identification of an omega-carboxy metabolite of lipoxin B4. Eur. J. Biochem. 224, 959-965.

56. Clish, C.B., O'Brien, J.A., Gronert, K., Stahl, G.L., Petasis, N.A., and Serhan, C.N. (1999) Local and systemic delivery of a stable aspirin-triggered lipoxin prevents neutrophil recruitment in vivo. Proc. Natl. Acad. Sci. U. S. A. 96, 8247-8252.

57. Guilford, W.J., Bauman, J.G., Werner Skuballa, W., Shawn Bauer, S., Wei, G.P., Davey, D., Schaefer, C., Mallari, C., Terkelsen, J., Tseng, J.-L., Shen, J., Subramanyam, B., Schottelius, A.J., and Parkinson, J.F. (2004) Novel 3-oxa lipoxin A4 analogues with enhanced chemical and metabolic stability have anti-inflammatory activity in vivo. J. Med. Chem. 47, 2157-2165.

58. O'Sullivan, T.P., Vallin, K.S., Shah, S.T., Fakhry, J., Maderna, P., Scannell, M., Sampaio, A.L., Perretti, M., Godson, C., and Guiry, P.J. (2007) Aromatic lipoxin A4 and lipoxin B4 analogues display potent biological activities. J. Med. Chem. 50, 5894-5902.

59. Duffy, C.D., Maderna, P., McCarthy, C., Loscher, C.E., Godson, C., and Guiry, P.J. (2010) Synthesis and biological evaluation of pyridine-containing lipoxin A(4) analogues. Chem. Med. Chem. 5, 517-522.

60. Sun, Y.P., Tjonahen, E., Keledjian, R., Zhu, M., Yang, R., Recchiuti, A., Pillai, P.S., Petasis, N.A., and Serhan, C.N. (2009) Anti-inflammatory and pro-resolving properties of benzo-lipoxin A(4) analogs. Prostaglandins Leukot. Essent. Fatty Acids 81, 357-366.

61. Navarro-Xavier, R.A., Newson, J., Silveira, V.L., Farrow, S.N., Gilroy, D.W., and Bystrom, J. (2010) A new strategy for the identification of novel molecules with targeted proresolution of inflammation properties. J. Immunol. 184, $1516-1525$.

62. Christie, P.E., Spur, B.W., and Lee, T.H. (1992) The effects of lipoxin A4 on airway responses in asthmatic subjects. Am. Rev. Respir. Dis. 145, 1281-1284.

63. Levy, B.D., Lukacs, N.W., Berlin, A.A., Schmidt, B., Guilford, W.J., Serhan, C.N., and Parkinson, J.F. (2007) Lipoxin A4 stable analogs reduce allergic airway responses via mechanisms distinct from CysLT1 receptor antagonism. FASEB J. 21, 3877-3884.

64. Levy, B.D., De Sanctis, G.T., Devchand, P.R., Kim, E., Ackerman, K., Schmidt, B.A., Szczeklik, W., Drazen, J.M., and Serhan, C.N. (2002) Multi-pronged inhibition of airway hyper-responsiveness and inflammation by lipoxin A(4). Nat. Med. 8, 1018-1023.

65. Grumbach, Y., Quynh, N.V., Chiron, R., and Urbach, V. (2009) LXA4 stimulates ZO-1 expression and transepithelial electrical resistance in human airway epithelial (16HBE14o-) cells. Am. J. Physiol. Lung Cell. Mol. Physiol. 296, L101-108.

66. Celik, G.E., Erkekol, F.O., Misirligil, Z., and Melli, M. (2007) Lipoxin A4 levels in asthma: relation with disease severity and aspirin sensitivity. Clin. Exp. Allergy 37, 1494-1501.

67. Bonnans, C., Fukunaga, K., Levy, M.A., and Levy, B.D. (2006) Lipoxin A(4) regulates bronchial epithelial cell responses to acid injury. Am. J. Pathol. 168, 1064-1072.

68. El Kebir, D., József, L., Pan, W., Wang, L., Petasis, N.A., Serhan, C.N., and Filep, J.G. (2009) 15-Epi-lipoxin A4 inhibits myeloperoxidase signaling and enhances resolution of acute lung injury. Am. J. Respir. Crit. Care Med. 180, 311-319.

69. Jin, S.W., Zhang, L., Lian, Q.Q., Liu, D., Wu, P., Yao, S.L., and Ye, D.Y. (2007) Posttreatment with aspirin-triggered lipoxin A4 analog attenuates lipopolysaccharide-induced acute lung injury in mice: the role of heme oxygenase-1. Anesth. Analg. 104, 369-377.

70. $\quad$ Karp, C.L., Flick, L.M., Park, K.W., Softic, S., Greer, T.M., Keledjian, R., Yang, R., Uddin, J., Guggino, W.B., Atabani, S.F., Belkaid, Y., Xu, Y., Whitsett, J.A., Accurso, F.J., Wills-Karp, M., and Petasis, N.A. (2004) Defective lipoxin-mediated anti-inflammatory activity in the cystic fibrosis airway. Nat. Immunol. 5, 388-392.

71. Chiron, R., Grumbach, Y.Y., Quynh, N.V., Verriere, V., and Urbach, V. (2008) Lipoxin A(4) and interleukin-8 levels in cystic fibrosis sputum after antibiotherapy. J. Cyst. Fibros. 7, 463-468. 
72. Hashimoto, A., Hayashi, I., Murakami, Y., Sato, Y., Kitasato, H., Matsushita, R., Iizuka, N., Urabe, K., Itoman, M., Hirohata, S., and Endo, H. (2007) Antiinflammatory mediator lipoxin A4 and its receptor in synovitis of patients with rheumatoid arthritis. J. Rheumatol. 34, 2144-2153.

73. Zhang, L., Zhang, X., Wu, P., Li, H., Jin, S., Zhou, X., Li, Y., Ye, D., Chen, B., and Wan, J. (2008) BML-111, a lipoxin receptor agonist, modulates the immune response and reduces the severity of collagen-induced arthritis. Inflamm. Res. 57, 157-162.

74. Fiorucci, S., de Lima, O.M., Jr., Mencarelli, A., Palazzetti, B., Distrutti, E., McKnight, W., Dicay, M., Ma, L., Romano, M., Morelli, A., and Wallace, J.L. (2002) Cyclooxygenase-2-derived lipoxin A4 increases gastric resistance to aspirin-induced damage. Gastroenterology 123, 1598-1606.

75. Fiorucci, S., Distrutti, E., de Lima, O.M., Romano, M., Mencarelli, A., Barbanti, M., Palazzini, E., Morelli, A., and Wallace, J.L. (2003) Relative contribution of acetylated cyclo-oxygenase (COX)-2 and 5-lipooxygenase (LOX) in regulating gastric mucosal integrity and adaptation to aspirin. FASEB J. 17, 1171-1173.

76. Renda, G., Zurro, M., Romano, M., and De Caterina, R. (2010) Aspirin-triggered lipoxin in patients treated with aspirin and selective vs. nonselective COX-2 inhibitors. Br. J. Clin. Pharmacol. 69, 303-306.

77. Peskar, B.M., Ehrlich, K., Schuligoi, R., and Peskar, B.A. (2009) Role of lipoxygenases and lipoxin A(4)/annexin-1 receptor in gastric protection induced by $20 \%$ ethanol or sodium salicylate in rats. Pharmacology 84, 310-313.

78. Peskar, B.M., Ehrlich, K., Schuligoi, R., and Peskar, B.A. (2009) Role of lipoxygenases and the lipoxin A(4)/annexin 1 receptor in ischemia-reperfusion-induced gastric mucosal damage in rats. Pharmacology 84, 294-299.

79. Goh, J., Baird, A.W., O'Keane, C., Watson, R.W., Cottell, D., Bernasconi, G., Petasis, N.A., Godson, C., Brady, H.R., and MacMathuna, P. (2001) Lipoxin A(4) and aspirin-triggered 15-epi-lipoxin A(4) antagonize TNF-alpha-stimulated neutrophil-enterocyte interactions in vitro and attenuate TNF-alpha-induced chemokine release and colonocyte apoptosis in human intestinal mucosa ex vivo. J. Immunol. 167, 2772-2780.

80. Gewirtz, A.T., Collier-Hyams, L.S., Young, A.N., Kucharzik, T., Guilford, W.J., Parkinson, J.F., Williams, I.R., Neish, A.S., and Madara, J.L. (2002) Lipoxin a4 analogs attenuate induction of intestinal epithelial proinflammatory gene expression and reduce the severity of dextran sodium sulfate-induced colitis. J. Immunol. 168, 5260-5267.

81. Fiorucci, S, Wallace, J.L., Mencarelli, A., Distrutti, E., Rizzo, G., Farneti, S., Morelli, A., Tseng, J.-L., Suramanyam, B., Guilford, W.J., and Parkinson, J.F. (2004) A beta-oxidation-resistant lipoxin A4 analog treats hapten-induced colitis by attenuating inflammation and immune dysfunction. Proc. Natl. Acad. Sci. U. S. A. 101, 15736-15741.

82. Gronert, K., Gewirtz, A., Madara, J.L., and Serhan, C.N. (1998) Identification of a human enterocyte lipoxin A4 receptor that is regulated by interleukin (IL)-13 and interferon gamma and inhibits tumor necrosis factor alphainduced IL-8 release. J. Exp. Med. 187, 1285-1294.

83. Kucharzik, T., Gewirtz, A.T., Merlin, D., Madara, J.L., and Williams, I.R. (2003) Lateral membrane LXA4 receptors mediate LXA4's anti-inflammatory actions on intestinal epithelium. Am. J. Physiol. Cell Physiol. 284, C888-896.

84. Kure, I., Nishiumi, S., Nishitani, Y., Tanoue, T., Ishida, T., Mizuno, M., Fujita, T., Kutsumi, H., Arita, M., Azuma, T., and Yoshida, M. (2010) Lipoxin A(4) reduces lipopolysaccharide-induced inflammation in macrophages and intestinal epithelial cells through inhibition of nuclear factor-kappaB activation. J. Pharmacol. Exp. Ther. 332, 541548.

85. Badr, K.F., DeBoer, D.K., Schwartzberg, M., and Serhan, C.N. (1987) Lipoxin A4 antagonizes cellular and in vivo actions of leukotriene D4 in rat glomerular mesangial cells: evidence for competition at a common receptor. Proc. Natl. Acad. Sci. U. S. A. 86, 3438-3442.

86. Brady, H.R., Persson, U., Ballermann, B.J., Brenner, B.M., and Serhan, C.N. (1990) Leukotrienes stimulate neutrophil adhesion to mesangial cells: modulation with lipoxins. Am. J. Physiol. 259, F809-815.

87. McMahon, B., Stenson, C., McPhillips, F., Fanning, A., Brady, H.R., and Godson, C. (2000) Lipoxin A4 antagonizes the mitogenic effects of leukotriene D4 in human renal mesangial cells. Differential activation of MAP kinases through distinct receptors. J. Biol. Chem. 275, 27566-27575.

88. McMahon, B., Mitchell, D., Shattock, R., Martin, F., Brady, H.R., and Godson, C. (2002) Lipoxin, leukotriene, and PDGF receptors cross-talk to regulate mesangial cell proliferation. FASEB J. 16, 1817-1819.

89. Mitchell, D., Rodgers, K., Hanly, J., McMahon, B., Brady, H.R., Martin, F., and Godson, C. (2004) Lipoxins inhibit Akt/PKB activation and cell cycle progression in human mesangial cells. Am. J. Pathol. 164, 937-946.

90. Wu, S.H., Wu, X.H., Lu, C., Dong, L., Zhou, G.P., and Chen, Z.Q. (2006) Lipoxin A4 inhibits connective tissue growth factor-induced production of chemokines in rat mesangial cells. Kidney Int. 69, 248-256.

91. Leonard, M.O., Hannan, K., Burne, M.J., Lappin, D.W., Doran, P., Coleman, P., Stenson, C., Taylor, C.T., Daniels, F., Godson, C., Petasis, N.A., Rabb, H., and Brady, H.R. (2002) 15-Epi-16-(para-fluorophenoxy)-lipoxin A(4)-methyl ester, a synthetic analogue of 15 -epi-lipoxin A(4), is protective in experimental ischemic acute renal failure. J. Am. Soc. Nephrol. 13, 1657-1662.

92. Kieran, N.E., Doran, P.P., Connolly, S.B., Greenan, M.C., Higgins, D.F., Leonard, M., Godson, C., Taylor, C.T., Henger, A., Kretzler, M., Burne, M.J., Rabb, H., and Brady, H.R. (2003) Modification of the transcriptomic response to renal ischemia/reperfusion injury by lipoxin analog. Kidney Int. 64, 480-492.

93. Leedom, A.J., Sullivan, A.B., Dong, B., Lau, D., and Gronert, K. (2010) Endogenous LXA4 circuits are determinants of pathological angiogenesis in response to chronic injury. Am. J. Pathol. 176, 74-84. 
94. Gronert, K., Maheshwari, N., Khan, N., Hassan, I.R., Dunn, M., and Laniado Schwartzman, M. (2005) A role for the mouse 12/15-lipoxygenase pathway in promoting epithelial wound healing and host defense. J. Biol. Chem. 280, $15267-15278$.

95. Biteman, B., Hassan, I.R., Walker, E., Leedom, A.J., Dunn, M., Seta, F., Laniado-Schwartzman, M., and Gronert, K. (2007) Interdependence of lipoxin A4 and heme-oxygenase in counter-regulating inflammation during corneal wound healing. FASEB J. 21, 2257-2266.

96. Medeiros, R., Rodrigues, G.B., Figueiredo, C.P., Rodrigues, E.B., Grumman, A., Jr., Menezes-de-Lima, O., Jr., Passos, G.F., and Calixto, J.B. (2008) Molecular mechanisms of topical anti-inflammatory effects of lipoxin A(4) in endotoxin-induced uveitis. Mol. Pharmacol. 74, 154-161.

97. Jin, Y., Arita, M., Zhang, Q., Saban, D.R., Chauhan, S.K., Chiang, N., Serhan, C.N., and Dana, R. (2009) Antiangiogenesis effect of the novel anti-inflammatory and pro-resolving lipid mediators. Invest. Ophthalmol. Vis. Sci. 50, 4743-4752.

98. Leedom, A.J., Sullivan, A.B., Dong, B., Lau, D., and Gronert, K. (2010) Endogenous LXA4 circuits are determinants of pathological angiogenesis in response to chronic injury. Am. J. Pathol. 176, 74-84.

99. Brezinski, M.E., Gimbrone, M.A., Jr., Nicolaou, K.C., and Serhan, C.N. (1989) Lipoxins stimulate prostacyclin generation by human endothelial cells. FEBS Lett. 245, 167-172.

100. Lefer, A.M., Stahl, G.L., Lefer, D.J., Brezinski, M.E., Nicolaou, K.C., Veale, C.A., Abe, Y., and Smith, J.B. (1988) Lipoxins A4 and B4: comparison of icosanoids having bronchoconstrictor and vasodilator actions but lacking platelet aggregatory activity. Proc. Natl. Acad. Sci. U. S. A. 85, 8340-8344.

101. Paul-Clark, M.J., Van Cao, T., Moradi-Bidhendi, N., Cooper, D., and Gilroy, D.W. (2004) 15-Epi-lipoxin A4mediated induction of nitric oxide explains how aspirin inhibits acute inflammation. J. Exp. Med. 200, 69-78.

102. Nascimento-Silva, V., Arruda, M.A., Barja-Fidalgo, C., and Fierro, I.M. (2007) Aspirin-triggered lipoxin A4 blocks reactive oxygen species generation in endothelial cells: a novel antioxidative mechanism. Thromb. Haemost. 97, 8898.

103. Fierro, I.M., Kutok, J.L., and Serhan, C.N. (2002) Novel lipid mediator regulators of endothelial cell proliferation and migration: aspirin-triggered-15R-lipoxin A(4) and lipoxin A(4). J. Pharmacol. Exp. Ther. 300, 385-392.

104. Cezar-de-Mello, P.F., Nascimento-Silva, V., Villela, C.G., and Fierro, I.M. (2006) Aspirin-triggered lipoxin A4 inhibition of VEGF-induced endothelial cell migration involves actin polymerization and focal adhesion assembly. Oncogene 25, 122-129.

105. Merched, A.J., Ko, K., Gotlinger, K.H., Serhan, C.N., and Chan, L. (2008) Atherosclerosis: evidence for impairment of resolution of vascular inflammation governed by specific lipid mediators. FASEB J. 22, 3595-3606.

106. Aliberti, J., Hieny, S., Reis e Sousa, C., Serhan, C.N., and Sher, A. (2002) Lipoxin-mediated inhibition of IL-12 production by DCs: a mechanism for regulation of microbial immunity. Nat. Immunol. 3, 76-82.

107. Aliberti, J., Serhan, C., Sher, A. (2002) Parasite-induced lipoxin A4 is an endogenous regulator of IL-12 production and immunopathology in Toxoplasma gondii infection. J. Exp. Med. 196, 1253-1262.

108. Bannenberg, G.L., Aliberti, J., Hong, S., Sher, A., and Serhan, C. (2004) Exogenous pathogen and plant $15-$ lipoxygenase initiate endogenous lipoxin A4 biosynthesis. J. Exp. Med. 199, 515-523.

109. Bafica, A., Scanga, C.A., Serhan, C., Machado, F., White, S., Sher, A., and Aliberti, J. (2005) Host control of Mycobacterium tuberculosis is regulated by 5-lipoxygenase-dependent lipoxin production. J. Clin. Invest. 115, 16011606.

110. Chen, M., Divangahi, M., Gan, H., Shin, D.S., Hong, S., Lee, D.M., Serhan, C.N., Behar, S.M., and Remold, H.G. (2008) Lipid mediators in innate immunity against tuberculosis: opposing roles of PGE2 and LXA4 in the induction of macrophage death. J. Exp. Med. 205, 2791-12801.

111. Pouliot, M., Clish, C.B., Petasis, N.A., Van Dyke, T.E., and Serhan, C.N. (2000) Lipoxin A(4) analogues inhibit leukocyte recruitment to Porphyromonas gingivalis: a role for cyclooxygenase-2 and lipoxins in periodontal disease. Biochemistry 39, 4761-4768.

112. Serhan, C.N., Jain, A., Marleau, S., Clish, C., Kantarci, A., Behbehani, B., Colgan, S.P., Stahl, G.L., Merched, A., Petasis, N.A., Chan, L., and Van Dyke, T.E. (2003) Reduced inflammation and tissue damage in transgenic rabbits overexpressing 15-lipoxygenase and endogenous anti-inflammatory lipid mediators. J. Immunol. 171, 6856-6865.

113. Chiang, N., Gronert, K., Clish, C.B., O'Brien, J.A., Freeman, M.W., and Serhan, C.N. (1999) Leukotriene B4 receptor transgenic mice reveal novel protective roles for lipoxins and aspirin-triggered lipoxins in reperfusion. J. Clin. Invest. 104, 309-316.

114. Planaguma, A., Titos, E., Lopez-Parra, M., Gaya, J., Puedo, G., Arroyo, V., and Claria, J. (2002) Aspirin (ASA) regulates 5-lipoxygenase activity and peroxisome proliferator-activated receptor alpha-mediated CINC-1 release in rat liver cells: novel actions of lipoxin A4 (LXA4) and ASA-triggered 15-epi-LXA4. FASEB J. 16, 1937-1939.

115. Ye, X.H., Wu, Y., Guo, P.P., Wang, J., Yuan, S.Y., Shang, Y., and Yao, S.L. (2010) Lipoxin A(4) analogue protects brain and reduces inflammation in a rat model of focal cerebral ischemia reperfusion. Brain Res. [Epub ahead of print]

116. Souza, D.G., Fagundes, C.T., Amaral, F.A., Cisalpino, D., Sousa, L.P., Vieira, A.T., Pinho, V., Nicoli, J.R., Vieira, L.Q., Fierro, I.M., and Teixeira, M.M. (2007) The required role of endogenously produced lipoxin A4 and annexin-1 for the production of IL-10 and inflammatory hyporesponsiveness in mice. J. Immunol. 179, 8533-8543. 
117. Fiore, S., Maddox, J.F., Perez, H.D., and Serhan, C.N. (1994) Identification of a human cDNA encoding a functional high affinity lipoxin A4 receptor. J. Exp. Med. 180, 253-260.

118. Takano, T., Fiore, S., Maddox, J.F., Brady, H.R., Petasis, N.A., and Serhan, C.N. (1997) Aspirin-triggered 15-epilipoxin A4 (LXA4) and LXA4 stable analogues are potent inhibitors of acute inflammation: evidence for antiinflammatory receptors. J. Exp. Med. 185, 1693-1704.

119. Ye, R.D., Boulay, F., Wang, J.M., Dahlgren, C., Gerard, C., Parmentier, M., Serhan, C.N., and Murphy, P.M. (2009) International Union of Basic and Clinical Pharmacology. LXXIII. Nomenclature for the formyl peptide receptor (FPR) family. Pharmacol. Rev. 61, 119-161.

120. Romano, M., Recchia, I., and Recchiuti, A. (2007) Lipoxin receptors. TheScientificWorldJOURNAL 7, $1393-1412$.

121. Krishnamoorthy, S., Recchiuti, A., Chiang, N., Yacoubian, S., Lee, C.H., Yang, R., Petasis, N.A., and Serhan, C.N. (2010) Resolvin D1 binds human phagocytes with evidence for proresolving receptors. Proc. Natl. Acad. Sci. U. S. A. 107, 1660-1665.

122. Devchand, P.R., Arita, M., Hong, S., Bannenberg, G., Moussignac, R.L., Gronert, K., and Serhan, C.N. (2003) Human ALX receptor regulates neutrophil recruitment in transgenic mice: roles in inflammation and host defense. FASEB J. 17, 652-659.

123. Dufton, N., Hannon, R., Brancaleone, V., Dalli, J., Patel, H.B., Gray, M., D'Acquisto, F., Buckingham, J.C., Perretti, M., and Flower, R.J. (2010) Anti-inflammatory role of the murine formyl-peptide receptor 2: ligand-specific effects on leukocyte responses and experimental inflammation. J. Immunol. 184, 2611-2619.

This article should be cited as follows:

Romano, M. (2010) Lipoxin and aspirin-triggered lipoxins. TheScientificWorldJOURNAL 10, 1048-1064. DOI 10.1100/tsw.2010.113. 

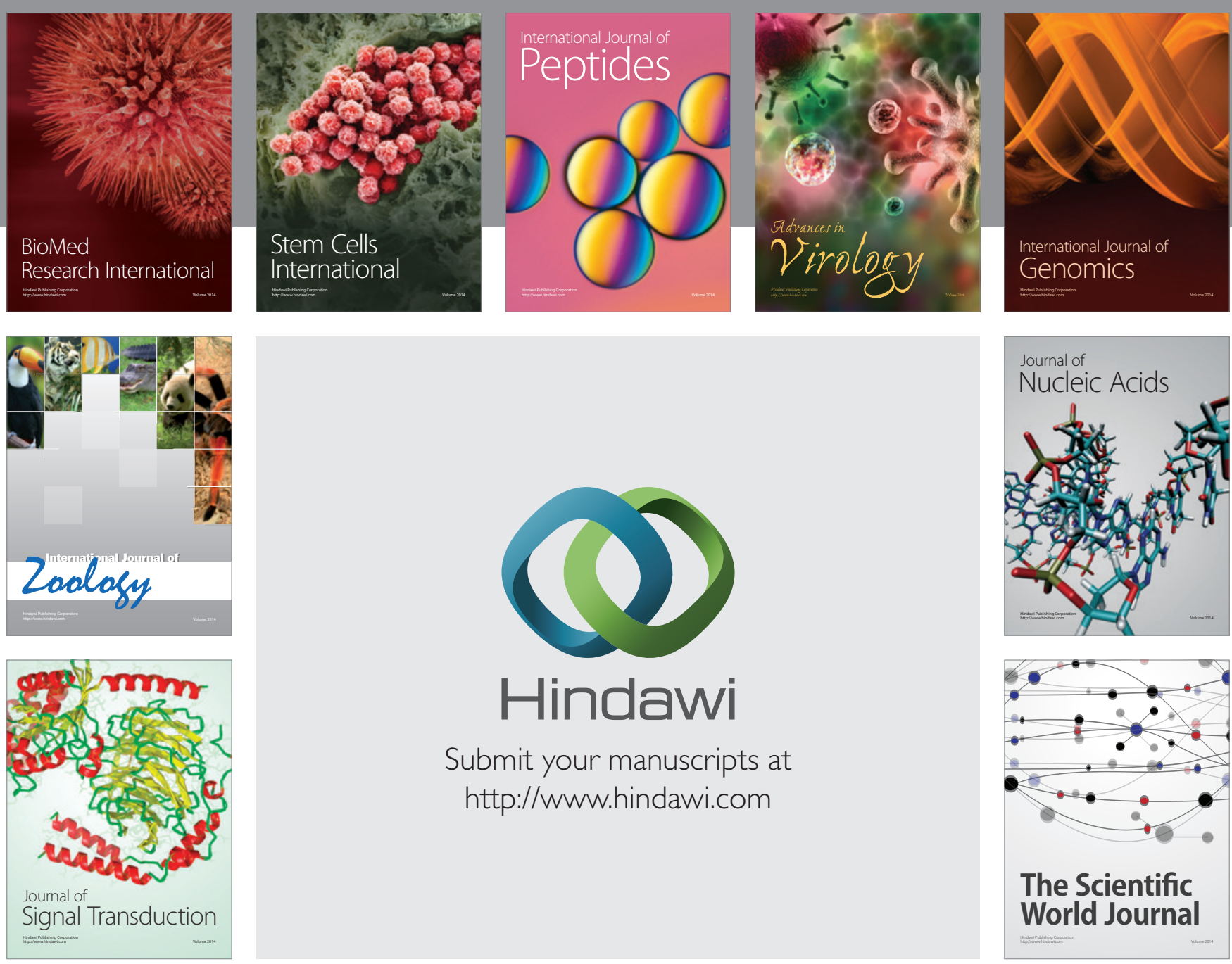

Submit your manuscripts at

http://www.hindawi.com
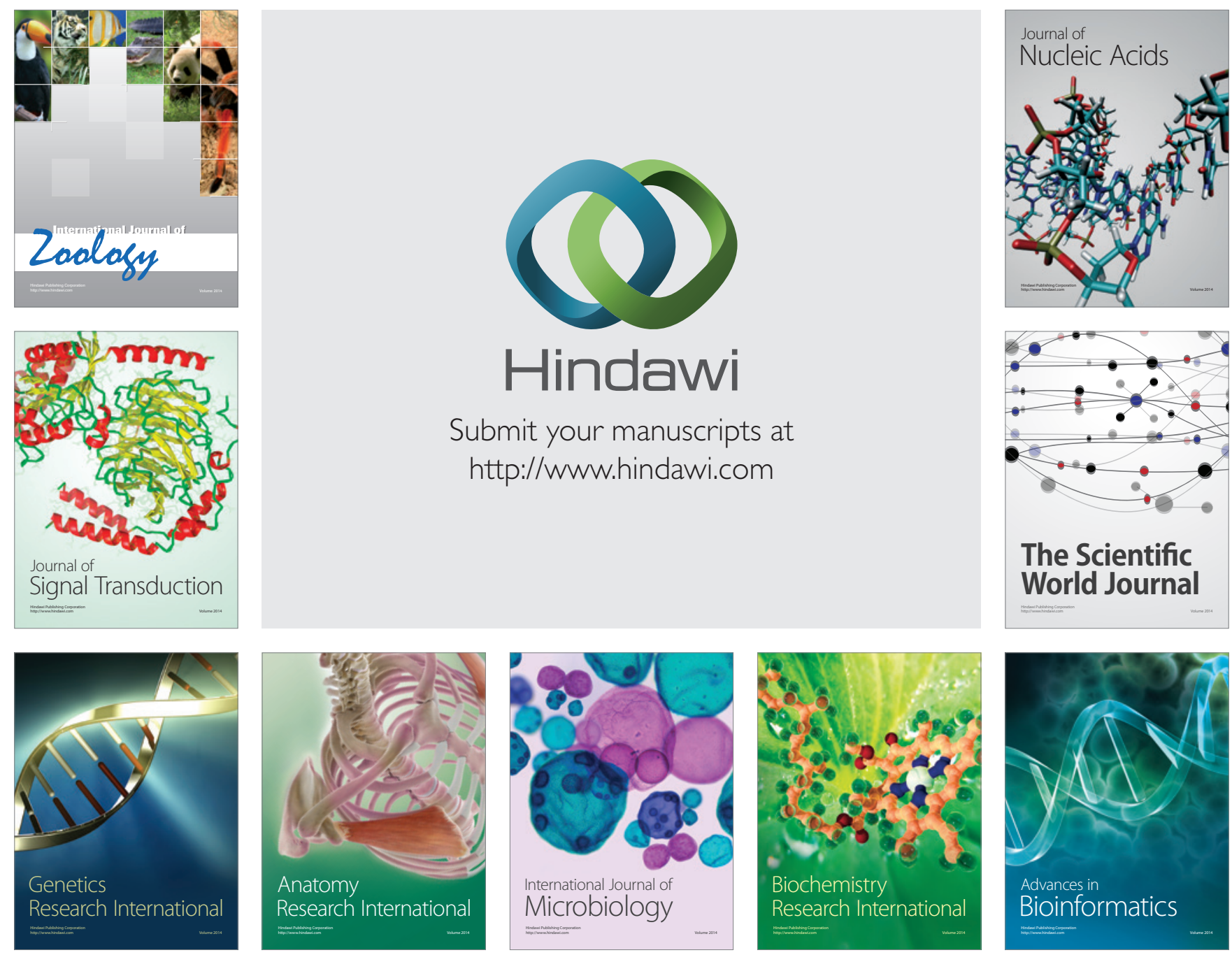

The Scientific World Journal
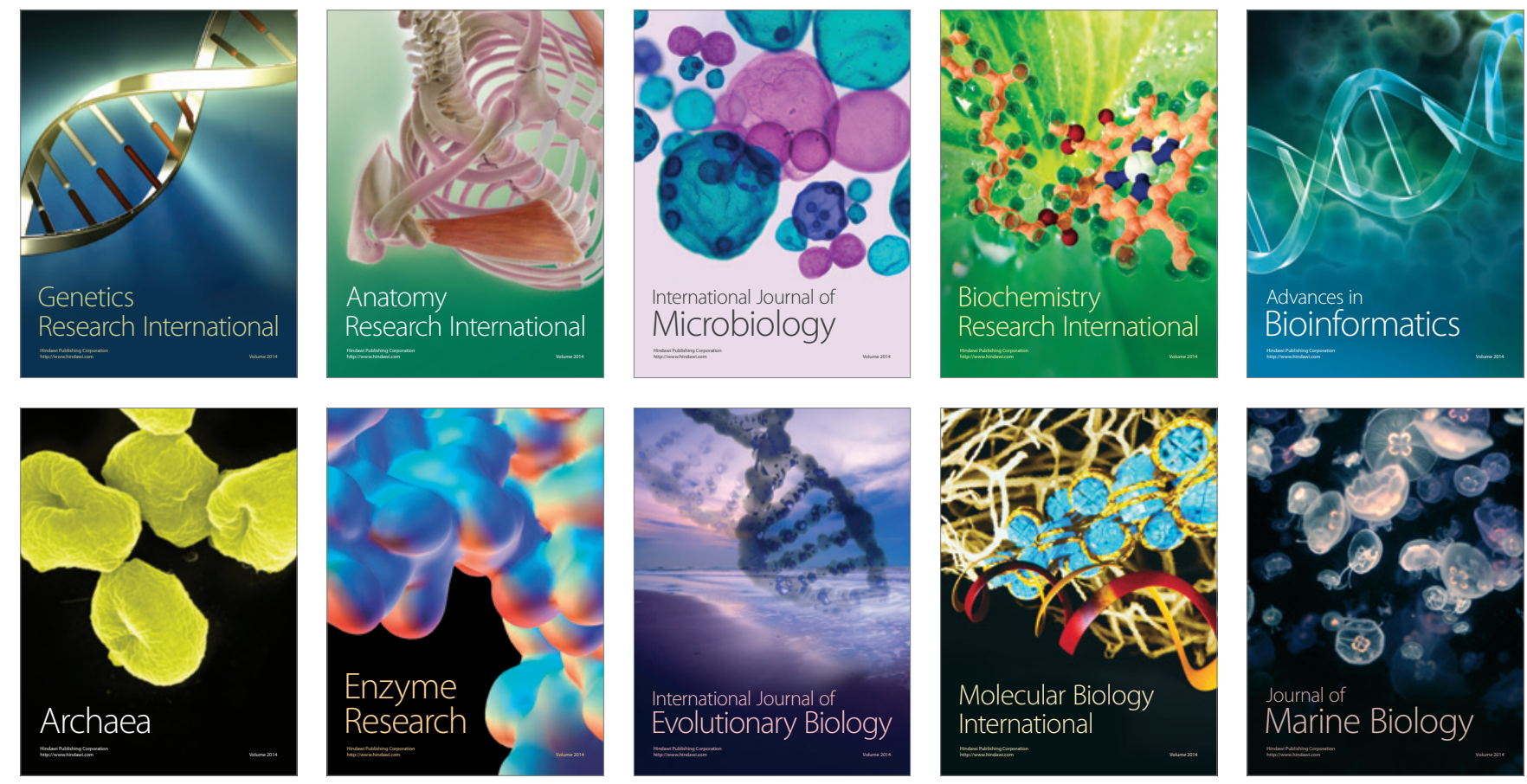